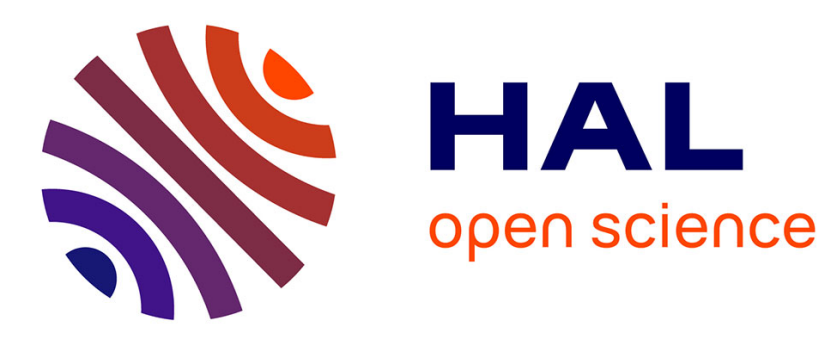

\title{
Price Points and Price Rigidity
}

Daniel Levy, Dongwon Lee, Haipeng Allan Chen, Robert S. Kauffman, Mark Bergen

\section{To cite this version:}

Daniel Levy, Dongwon Lee, Haipeng Allan Chen, Robert S. Kauffman, Mark Bergen. Price Points and Price Rigidity. Review of Economics and Statistics, 2011, 93 (4), pp.1417-1431. 10.1162/REST_a_00178. hal-02387737

\section{HAL Id: hal-02387737 https://hal.science/hal-02387737}

Submitted on 30 Nov 2019

HAL is a multi-disciplinary open access archive for the deposit and dissemination of scientific research documents, whether they are published or not. The documents may come from teaching and research institutions in France or abroad, or from public or private research centers.
L'archive ouverte pluridisciplinaire HAL, est destinée au dépôt et à la diffusion de documents scientifiques de niveau recherche, publiés ou non, émanant des établissements d'enseignement et de recherche français ou étrangers, des laboratoires publics ou privés. 


\title{
Price Points and Price Rigidity
}

\author{
Daniel Levy* \\ Bar-Ilan University and RCEA \\ Levyda@mail.biu.ac.il
}

\section{Dongwon Lee}

Korea University

mislee@korea.ac.kr

\section{Haipeng (Allan) Chen}

Texas A\&M University hchen@mays.tamu.edu

Robert J. Kauffman

Arizona State University

rkauffman@asu.edu

Mark Bergen

University of Minnesota

mbergen@csom.umn.edu

Last revision: November 26, 2010

JEL Codes: E31, L16, D80, M21, M30

Key Words: Price Point, 9-Ending Price, Price Rigidity 


\title{
Price Points and Price Rigidity
}

\begin{abstract}
We study the link between price points and price rigidity, using two datasets: weekly scanner data, and Internet data. We find that: "9" is the most frequent ending for the penny, dime, dollar and ten-dollar digits; the most common price changes are those that keep the price endings at "9"; 9-ending prices are less likely to change than non-9-ending prices; and the average size of price change is larger for 9-ending than non-9-ending prices. We conclude that 9-ending contributes to price rigidity from penny to dollar digits, and across a wide range of product categories, retail formats and retailers.
\end{abstract}


Acknowledgements: We thank two anonymous referees and the editor Mark Watson for constructive comments and suggestions. We thank Jurek Konieczny, the discussant at the CEU Conference on "Microeconomic Pricing and the Macroeconomy" for comments, and the conference participants: Marco Bonomo, Alan Kackmeister, Attila Ratfai, Julio Rotemberg, Harald Stahl, Jonathan Willis and Alex Wolman for suggestions. Gershon Alperovich, Bob Barsky, Alan Blinder, Leif Danziger, Mark Gertler, Carlos Marques and Jacob Paroush provided helpful comments. We thank the seminar participants at Bar-Ilan University, Ben-Gurion University, Deutsche Bundesbank, Emory University, European Central Bank, Hebrew University, Federal Reserve Bank of Kansas City, Magyar Nemzeti Bank, Texas A\&M University, University of Minnesota, University of Piraeus, and Tel-Aviv University for comments. We thank Péter Benczúr, Michael Ehrmann, David Genesove, Peter Gabriel, Zvi Hercowitz, Heinz Herrmann, Johannes Hoffmann, Péter Karádi, Ed Knotek, Saul Lach, Benoît Mojon, Ádám Reiff, and Frank Smets for comments, Manish Aggrawal, Ning Liu, and Avichai Snir for research assistance. Portions of this work have been also presented at the 2004 INFORMS Conference on Information Systems and Technology, the 2004 International Conference on Systems Science, the 2005 IS Research Symposium, the 2006 Minnesota Symposium on Statistical Challenges in E-Commerce, the 2005 AMCIS Doctoral Consortium, and at the 2005 INFORMS Marketing Science Conference. We thank Chris Forman, Hemant Bhargava, D.J. Wu, Barrie Nault, Fred Riggins, Sri Narasimhan, Rahul Telang, Sunil Milthas, and other conference participants for helpful suggestions. Some parts of this manuscript were completed at the Monetary Policy and Research Division, at the Research Department of the European Central Bank, where Daniel Levy was a visiting scholar. He is grateful to the Bank's Research Department for the hospitality. Daniel Levy gratefully acknowledges also the financial 
support from the Adar Foundation of the Economics Department at Bar-Ilan University. Dongwon Lee's research is supported by an eBRC Doctoral Support Award from Pennsylvania State University and a Research Grant from Korea University. Rob Kauffman acknowledges partial support from the MIS Research Center, and the W.P. Carey Chair in Information Systems, Arizona State University. All authors contributed equally: we rotate co-authorship. The usual disclaimer applies.

* Corresponding author: Daniel Levy, Levyda@mail.biu.ac.il. 
Nor does anyone know how important ... [price points] are in practice.

Alan Blinder et al. (1998, p. 26)

\section{Introduction}

With the increased popularity of new Keynesian models, understanding the sources of nominal price rigidity has become even more important. ${ }^{1}$ One of the recent theories of price rigidity is price point theory, which Blinder et al. (1998) list among the twelve leading theories of price rigidity. According to the authors (p. 26), practitioners' “... belief in pricing points is part of the folklore of pricing ...” Consistent with this observation, they offer evidence from interviews on the importance of price points. In their study of 200 U.S. firms, they found that 88 percent of retailers assigned substantial importance to price points in their pricing decisions. Kashyap (1995), the first to explore the link between price points and price rigidity, found that catalog prices tended to be "stuck" at certain ending prices. After concluding that the observation cannot be explained by existing theories, he offered price point theory as a possible explanation.

As Blinder et al. (1998) note in the opening quote above, however, a major difficulty with price point theory is that not much is known about the actual importance of price points or about their relationship to price rigidity. Price points will be particularly important for macroeconomics if they can be shown to contribute to price rigidity across a wide range of products and retailers. The literature offers growing evidence on the use of price points, but still there is a lack of direct evidence linking price points and price rigidity. The literature documenting a link between price points and price rigidity using U.S. data is limited to Kashyap (1995) and Blinder et al. (1998). Kashyap has emphasized the need for more direct evidence, stating that a "study focusing on more goods ... would have much more power to determine the significance of price points.”

Our goal is to fill this gap in the literature by offering new evidence on the link between 
price points and price rigidity using two particularly appropriate but different datasets. One is a large weekly scanner price dataset from a major Midwestern U.S. retailer, covering 29 product categories over an eight-year period. The second comes from the Internet and includes daily prices over a two-year period for 474 consumer electronic goods, such as music CDs, digital cameras, notebook PCs, etc., from 293 different e-retailers, with a wide range of prices. Taken together, the two datasets cover a diverse set of products, a wide range of prices, different retail formats, and multiple retailers and time periods.

The following summarizes our findings. "9" is the most popular price point for the penny, dime, dollar and the ten-dollar digits across the two datasets. The most common price changes are those that keep the terminal digits at these "9"endings. When we estimated the probability of a price change, we found that the 9-ending prices are less likely to change in comparison to non 9-ending prices. For the Dominick’s data 9-ending prices are at least 43-66 percent less likely to change than non-9-ending prices. For the Internet data, these probabilities are in the range of 2564 percent. The average size of the 9-ending price changes are larger in comparison to non-9ending prices, which further underscore the extent of the 9-ending price rigidity.

The paper is organized as follows. We describe the data in section II. In section III, we study the distribution of price-endings. In section IV, we assess the distribution of price changes. In section $\mathrm{V}$, we estimate the effect of 9-endings and 99-endings on price rigidity. In section VI, we evaluate the link between price points and the size of price changes. In section VII, we discuss the robustness of the findings. Section VIII concludes.

\section{Two Datasets}

Kashyap’s (1995) price point theory suggests that price points should be most important to retail firms (Blinder et al. 1998, Stahl 2010). We examine retail prices from two large datasets. 
One is Dominick’s weekly price data for 29 different supermarket product categories over an eight-year period. The other contains daily prices from the Internet on products that include music CDs, DVDs, hard disks, and notebook PCs, among others.

The two datasets cover a wide variety of products, a wide range of prices, and different retail formats. In addition, although Dominick's prices are set on a chain-wide basis, our Internet data come from many different retailers, which presumably employ different pricing decision models. Thus, the conclusions that we draw are not specific to a particular retail format, a retailer, a product, or a price range.

Dominick's is a large supermarket chain in the Chicago metropolitan area. During the period of our study, it operated 93 stores with a market share of about 25 percent. The data consist of up to 400 weekly observations of retail prices in 29 different product categories, covering the period from September 14, 1989 to May 8, 1997. The prices are the actual transaction prices as recorded by the chain's checkout scanners. If an item was on sale, then the price data reflect the sale price of the item.

Although Dominick's prices are set on a chain-wide basis at the company headquarters, there is some price variation across the stores depending on the price tiers to which the stores belong. Dominick’s divides its stores into four price tiers. These are "Cub-fighter,” "low,” “medium,” and "high.” The stores designated as Cub-fighters are typically located in proximity to a Cub Foods store and thus compete directly with it. The other three price tier stores employ a pricing strategy that fits best given their local market structure and competition conditions.

We report results from analyzing the prices in four stores, one from each price tier. The stores were selected at random and include Store \#8 (“low” price tier), \#12 (“high” price tier), \#122 (“Cub Fighter”), and \#133 (“medium” price tier). To study the behavior of regular prices, 
we removed data points if they involved bonus buys, coupon-based sales, or simple price reductions. For this, we relied on Dominick’s data identifiers which indicated the occurrences of such promotions. Dominick’s did not use loyalty cards during the time period studied.

In total, the Dominick’s data contain over 98 million weekly price observations on 18,037 different grocery products in 29 product categories. ${ }^{2}$ The four-store sample contains 4,910,129 weekly price observations on 16,105 different products. Barsky et al. (2003),

Chevalier et al. (2003), and Levy et al. (2010) offer more details about the data. ${ }^{3}$ Table 1 presents descriptive statistics for the Dominick's data for the four stores.

Our Internet data were obtained through the use of a price data-gathering software agent. We programmed it to download price data from BizRate (www.bizrate.com), a popular price comparison site. It accessed the site for data collection from 3:00 a.m. to 5:00 a.m. over a period of more than two years from March 26, 2003 to April 15, 2005. We generated a large sample of product IDs using stratified proportionate random sampling (Wooldridge 2002) from a list of products available at BizRate. The software agent automatically built a panel of sales prices given the product IDs. ${ }^{4}$ The resulting dataset consists of 743 daily price observations for 474 personal electronic products in 10 product categories from 293 different Internet-based retailers. The categories include Music CDs, Movie DVDs, Video Games, Notebook PCs, Personal Digital Assistants (PDAs), Software, Digital Cameras and Camcorders, DVD Players, PC Monitors, and Hard Drives. ${ }^{5}$ In total, the Internet data contain over 2.5 million daily price observations. Table 2 presents descriptive statistics for the Internet data.

\section{Evidence on the Popularity of 9-Ending and 99-Ending Prices}

I asked the best economist I know, at least for such things-my wife, if she recalled a price not ending in a "9" at our local grocery store. "Not really," she 
said. "Maybe sometimes there are prices ending in a " 5 ," but not really."

Jurek Konieczny (2003, Discussant Comment)

We begin by presenting the results on the frequency distribution of price-endings in the two datasets. In the analysis of Dominick’s data, our focus was on $9 \$$ and $99 \$$ price-endings because the overwhelming majority of the prices in retail grocery stores were well below $\$ 10.00$ during the study period. ${ }^{6}$ In the Internet data, the price ranges were different: from a minimum of $\$ 3.99$ to a maximum of $\$ 6,000.00$, with the average prices in different categories spanning $\$ 13.46$ to $\$ 1,666.68$ in the study period. The wider price range in the Internet data enables us to study not only $9 \$$ and $99 \$$ price-endings, but also other 9-ending prices in both the cents and the dollars digits, including $\$ 9$, \$9.99, $\$ 99$, and $\$ 99.99$.

In Figure 1, we report the frequency distribution of the last digit of the prices in Dominick's data. If a digit's appearance as a price-ending were random, then we should have seen 10 percent of the prices ending with each digit. As the figure indicates, however, about 69 percent of the prices ended with a "9." The next most popular ending was " 5 ,” accounting for only 12 percent of all price endings. Only a small proportion of the prices ends with other digits.

Next, we consider the frequency distribution of the last two digits. With two digits, there are 100 possible endings, $00 \$, 01 \$, \ldots, 98 \$$, and $99 \$$. Thus, with a random distribution, the probability of each ending should be only 1 percent. According to Figure 2, however, most prices end with either $09 \$, 19 \$, \ldots$, or $99 \$$. This is not surprising since " 9 " was the dominant singledigit ending. But of these, more than 15 percent of the prices ended with 99๕. In contrast, only about 4 percent to 6 percent of the prices ended with 09థ, 19థ, ..., and $89 \$$.

Figure 3 displays the frequency distribution of the last digit in the Internet data. We can 
see that " 9 " was the most popular terminal digit (33.4 percent), followed by “0" (24.1 percent), and "5" (17.4 percent). The frequency distribution of the last two digits, which is shown on Figure 4, exhibits a similar pattern, with $99 \$$ as the most popular price-ending (26.7 percent), followed by $00 \$$ (20.3 percent), 95 $\$$ (13.8 percent), and 98 $\$$ (4.8 percent).

As mentioned above, the Internet dataset also includes some high-price product categories, which allowed us to examine price-endings in dollar digits as well. In Figure 5, therefore, we present the frequency distribution of the last dollar digit in the Internet data. According to the figure, “9” was the most popular ending for the dollar digit, with $\$ 9$ priceendings over-represented with 36.1 percent, followed by \$4 price-endings with 9.9 percent, and \$5 price-endings with 9.2 percent. The popularity of $\$ 4$ and $\$ 5$ ending prices stems from the fact that the actual prices in the low price product categories (Music CDs, Movie DVDs, and Video Games) often are in the \$14-\$15 range.

A similar pattern emerged for the last two dollar digits, as shown in Figure 6. Not surprisingly, the last two dollar digits of most prices contained “9” also, such as $\$ 99, \$ 89$, and \$09. But more prices ended with $\$ 99$ than any other two dollar digit endings. Moreover, almost 10 percent ended with $\$ 99$ among the 100 possible dollar endings of $\$ 0$ through $\$ 99$.

We also examined the frequency distribution of the last three digits of prices in the Internet data. According to Table 3 (first column), among the 1,000 possible endings \$9.99 was the most popular ending for the last three digits (13.2 percent), followed by $\$ 9.00$ (10.0 percent), and \$9.95 (4.9 percent). When we examined the last four digits of the prices (second column) among the 10,000 possible endings $\$ 99.99$ was the most popular ending (3.47 percent), followed by $\$ 99.00$ (3.46 percent), and $\$ 19.99$ (2.16 percent).

To summarize, in both datasets, "9" was the most popular terminal digit overall. But the 
popularity of "9" was not limited to the penny digit. Rather, it was popular in the dime, dollar, and ten-dollar digits too. The fact that our data include a variety of products with wide-ranging prices and different retail formats further underscores the popularity of " 9 ” and " 99 ” as a terminal cent and dollar digits.

\section{Frequency Distribution of Price Changes}

Having documented the dominance of "9" and "99" price endings as the terminal digits in both datasets, we next assessed the extent to which the specific price points "9" and "99" may be contributing to the retail price rigidity. To characterize the price change dynamics, we conducted a 10-state Markov chain analysis for price changes that affect one digit of a price (the penny digit and the dollar digit), and a 100-state Markov chain analysis for price changes that affect two digits of a price (the penny and the dime digits, and the dollar and the 10-dollar digits).

Table 4 displays the 10-state transition probability matrix for the penny digit for the Dominick's data at the four sampled stores. For ease of interpretation, the figures in the matrix (as well as in the remaining matrices) have been normalized, so that the probabilities in all rows and columns combined add up to 1 . Considering all 100 possible transition probabilities, it is clear that $9 \$$-ending prices are the most persistent: 37.87 percent of the $9 \mathbb{\$}$-ending prices preserve the $9 \mathbb{4}$-ending after the change. Moreover, when non $9 \mathbb{\$}$-ending prices change, they most often end up with $9 \mathbb{4}$-ending than with any other ending. Considering the diagonal elements of the matrix, after $9 \$$-ending prices, $5 \$$-ending prices seem to be the second most persistent with a

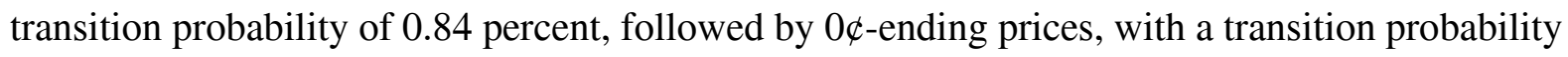

of 0.64 percent. Overall, however, it seems that most of the transition dynamics takes place in the

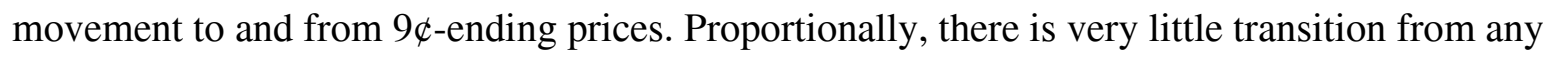
particular non-9\$-ending prices to another non- $9 \mathbb{\$}$-ending price. 
Table 5 displays the 10-state transition probability matrix for the penny digit for the Internet data. Focusing on the diagonal terms, we find that on the Internet $0 \$$-ending prices are the most persistent, with a transition probability of 20.35 percent. $9 \mathbb{\$}$-ending prices are the second most persistent with a transition probability of 17.68 percent, followed by $5 \$$-ending prices with a transition probability of 10.63 percent.

Table 6 displays the 10-state transition probability matrix for the dollar digit for the Internet data. Focusing on the diagonal terms, we find that $\$ 9$-ending prices are significantly more persistent than any other dollar-ending prices, with a transition probability of 11.75 percent. \$4-eding prices are the second most persistent with a transition probability of 2.73 percent, followed by $\$ 5$-ending prices with a transition probability of 2.52 percent. The persistence of the $\$ 4$ and $\$ 5$ endings stems from the fact that many price changes in the low price product categories (Music CDs, Movie DVDs, and Video Games) take place in the penny and in the dime digits.

Comparing the figures presented in Tables 5 and 6, it appears that the Internet retailers tend not to use $9 \mathbb{\$}$-ending proportionally as often. Instead, they use \$9-ending more often. Thus, the use of 9 as a terminal digit increases as we move from the penny and dime digits to the dollar and the 10-dollar digits. Below we offer more evidence consistent with this behavior.

We next report the results of 100-state Markov chain analysis for the terminal two-digits of the price, for the penny and the dime digits for both data sets, and for the dollar and the 10dollar digits for the Internet data. The resulting transition probability matrix, however, is $100 \times$ 100. We, therefore, present only partial results of these analyses. The figures presented in these matrices are normalized as before, so that the probabilities in the entire table add up to 1 . 
Table 7 lists the top 25 transition probabilities for the penny and the dime digits at the four Dominick's stores. According to these figures, the most common transitions are from $89 \$-$ ending prices to $99 \$$-ending prices with the transition probabilities of 1.34 percent, 1.09 percent, 0.87 percent, and 0.82 percent, for Stores \#8, \#12, \#122, and \#133, respectively. These probabilities seem quite high considering the fact that in the 100-state Markov chain there are 10,000 possible transitions. The second most common movement is from a $99 \$$-ending to a $89 \$$ ending with the transition probability of 1.03 percent, 0.86 percent, and 0.70 percent, at Stores $\# 8$, \#12, and \#122, respectively. In Store \#122, the second most common movement is from a $39 \$$-ending to a $49 \$-$-ending, with a transition probability of 0.65 percent. The third most common movement in Stores \#8 and \#122 is from a $99 \$$-ending to a $19 \$$-ending with the transition probability of 0.86 percent and 0.61 percent, respectively, in Store $\# 12$ from a $79 \AA$ ending to a $99 \$$-ending with a transition probability of 0.83 percent, and in Store \#133 from a $79 \$$-ending to a $89 \$$-ending with a transition probability of 0.62 percent.

The transition from 994 -ending prices to 994 -ending prices come only in the $13^{\text {th }}, 12^{\text {th }}$, $15^{\text {th }}$ and $18^{\text {th }}$ places for Stores \#8, \#12, \#122, and \#133, respectively, with the corresponding transition probabilities of 0.66 percent, 0.61 percent, 0.43 percent, and 0.43 percent. While these figures are quite high, it appears that other movements are more dominant than this particular transition. The reason for this, we believe, is the fact that the average price in the Dominick's data is \$2.67. Moreover, in all but two product categories, Analgesics and Laundry Detergents (Beer and Cigarette categories are not discussed as mentioned in footnote 2), the average prices are $\$ 3.00$ or less. A move from a $99 \$$-ending price to a $99 \$$-ending price, therefore, will result in a minimum price increase of 33-50 percent on average and a minimum price decrease of 25-33 
percent, on average. Changes of this magnitude seem fairly large and, therefore, we suspect that they are not as frequent.

Table 8 lists the top 25 transition probabilities for the internet data, for the penny and dime digits on the left-hand side and for the dollar and the 10-dollar digits on the right-hand side. The top three transitions for the penny and dime digits are from $00 \$$-ending prices to $00 \$$-ending prices with a transition probability of 18.36 percent, from $99 \$$-ending prices to 994 -ending prices with a transition probability of 11.89 percent, and from $95 \$$-ending prices to $95 \$$-ending prices with a transition probability of 8.83 percent. The top three transitions for the dollar and the 10 dollar digits are from \$14-ending prices to \$14-ending prices with a transition probability of 1.47 percent, from \$11-ending prices to \$11-ending prices with a transition probability of 1.36 percent, and from \$15-ending prices to \$15-ending prices with a transition probability of 1.28 percent. The transition from $\$ 99$-ending price to $\$ 99$-dollar ending price came in only the $6^{\text {th }}$. The frequent use of the \$11-, \$14-, and \$15-ending prices stems from the fact that in the low-priced product categories which include Music CD’s, Movie DVD’s and Video Games’ categories, these are not just price endings; these are actual prices. In these categories, therefore, the most common price changes are in the penny and the dime digits, which leave the dollar and the 10-dollar digits unchanged.

This finding suggests that price change patterns likely differ between low-priced and high-priced product categories. To explore this possibility, we separated the Internet data into two groups: (1) low-priced product categories which include Music CDs, Movie DVDs, and Video Games, and (2) high-priced product categories which include Computer Monitors, Digital Cameras, DVD Players, Hard Drives, Laptop Computers, PDAs, and Software. 
The results of the analyses are reported in Table 9. Beginning with the low-priced product categories, we find that for the penny and the dime digits, the most common transition is from $99 \$$-ending to $99 \$$-ending with a transition probability of 16.32 percent, followed by a movement from $98 \$$-ending to $98 \$$-ending with a transition probability of 1.80 percent, and a movement from 95\$-ending to 95\$-ending with a transition probability of 1.75 percent. For the dollar and the \$10 digits, we find that \$14-, \$11-, and \$15-ending prices are the most popular.

Next, moving to the high priced product categories, we find that for the penny and the

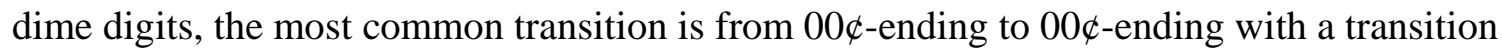
probability of 28.59 percent, followed by a movement from 95\$-ending to 95\$-ending with a transition probability of 12.77 percent, and a movement from $99 \$$-ending to $99 \$$-ending with a transition probability of 9.42 percent. For the dollar and the 10-dollar digits, we find that the top three transition probabilities are from $\$ 99$-ending prices to $\$ 99$-ending prices with a transition probability of 1.51 percent, from $\$ 99$-ending prices to \$49-ending prices with a transition probability of 0.65 percent, and from \$49-ending prices to \$99-ending prices with a transition probability of 0.60 percent.

In sum, we find that for the low-priced product categories, price changes that keep the terminal digits at " 9 " are the most popular in the penny digit, in the penny and dime digits, and in the dollar digit. For the high-priced product categories, price changes that keep the terminal digits at "9" are the most popular in the dollar digit, and in the dollar and 10-dollar digits. These results suggest that the persistent use of 9-ending prices is more likely to occur in the right-most digits for low-priced products, but shift to the left as the products became more expensive. This is consistent with the finding discussed above that " 994 "-to-“99థ” transitions were less common in the Dominick’s dataset, which consists of mostly low-priced products. 


\section{The Effect of Price Points on Price Rigidity}

To study the link between 9-ending prices and price rigidity more directly, we use a binomial logit model to estimate price change probabilities. Using the method of maximum likelihood, we estimated the parameters $\alpha, \beta$ and $\gamma$ of the following equation:

$$
\ln (q /(1-q))=\alpha+\beta \text { 9_Ending } j t+\gamma \text { Product }_{j t}+\varepsilon_{t}
$$

where $q$ is the probability of a price change and 9_Ending $g_{j t}$ is a 9-ending dummy variable. For the Dominick's data, we estimate two versions of the regression. In the first, the 9_Ending ${ }_{j t}$ dummy equals 1 if the price for product $j$ at time $t$ ends with " 94 ” and 0 otherwise. In the second regression, the 9_Ending $j$ dummy equals 1 if the price for product $j$ at time $t$ ends with " 994 " and 0 otherwise. For the Internet data, we estimate six versions of the regression, corresponding to

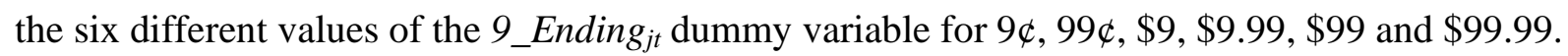

Product $_{j t}$ represents a set of product-specific dummy variables based on universal product codes (UPCs) in the Dominick's data and other unique product identifiers in the Internet data. They permit us to account for product-specific effects. For example, products for which 9-ending prices are more common, may tend to be more rigid. ${ }^{7}$

The estimation results for the Dominick’s data are reported in Table 10. In the table, we present the estimated coefficients of each dummy along with the corresponding odds ratios. For all 27 product categories, the coefficient estimates for the $9 \$$-ending dummy are negative (all $p$ values $<0.0001)$. The odds ratios, which equal $e^{\text {Coefficient }}$, are all smaller than 1 , indicating that

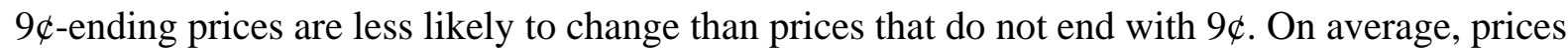
that ended with $9 \$$ were 66 percent less likely to change than prices that did not end with $9 \mathbb{4}$.

We obtained similar results for the $99 \$$-ending prices. The coefficient estimates for the 
99\$-ending dummy are all negative. For 25 out of 27 categories, they are statistically significant, as shown on the right-hand panel in Table 10. The odds ratios indicate that prices that ended with $99 \$$ were on average 43 percent less likely to change than prices that did not end with $99 \$$.

Next, we estimated the same logit regression model for the Internet data, using dummies for $9 \$, 99 \$, \$ 9, \$ 9.99, \$ 99$, and $\$ 99.99$, in turn, as the independent variables. As with the Dominick's dataset, we included product dummies to account for product-specific effects. The estimation results are reported in Table 11. Similar to what we found with the Dominick's dataset, 9-ending prices were less likely to change than other prices. Overall, $9 \mathbb{4}$-ending prices were 25 percent, 99\$-ending prices 36 percent, \$9-ending prices 36 percent, \$99-ending prices 55 percent, \$9.99-ending prices 45 percent, and \$99.99-ending prices 64 percent less likely to change than other prices. We obtained similar results for the individual product categories. In 96 percent (52 out of 54 categories) of all possible cases in the category-level analyses, the effect of 9 price-endings on the probability of price changes was negative and significant.

Thus, prices seem to be “stuck” at 9- and 99-endings, making them more rigid: $9 \$$ - and 994-ending prices at Dominick’s as well as on the Internet are less likely to change than other prices. On the Internet, the findings hold also for \$9-, \$9.99-, \$99-, and \$99.99-ending prices.

\section{The Effect of Price Points on the Size of Price Change}

If pricing points inhibit price changes, then they might also be expected to affect the sizes of price increases. Specifically if prices that are at price points are fixed longer than other prices, then any subsequent price adjustments might be expected to be larger than average. 
If 9-ending prices are less likely to change in comparison to non-9-ending prices, then the average size of change of 9-ending prices should be larger when they do change, in comparison to non-9-ending prices. This assumes that the cost of a price change is the same regardless of the price-ending, which we believe is indeed the case according to the menu cost estimates of Levy et al. (1997, 1998, 2008), Zbaracki, et al. (2004, 2007), and Dutta et al. (1999) for large U.S. supermarket and drugstore chains.

In Table 12, we report the average size of price changes for 9-ending and non-9-ending prices for both datasets. In the table, we also report the corresponding results for the low quartile of the products in terms of the popularity of 9-ending prices. The goal of this analysis is to assess the possibility that the findings we are documenting in this section may be driven by the frequent use of 9-endings. By limiting the analysis to the low quartile of the products in terms of the use of 9-endings, we are offering the most conservative test for this hypothesis.

In the Dominick’s dataset, the average price change was $75 \mathbb{4}$ if the price ended with $9 \mathbb{}$, in contrast to a $40 \$$ change when it did not end with $9 \mathbb{}$, an 88 percent difference. The findings for the 99\$-ending prices are also consistent: the average price change was $91 \$$ if the price ended with $99 \$$, in contrast to a 55 change when it did not end with 994 . This amounts to a 65 percent difference.

Similarly, when we focused on the low quartile of products in terms of the popularity of

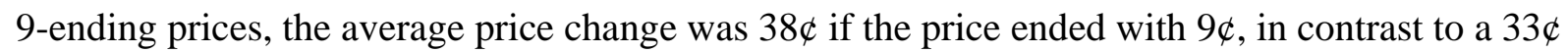
change when it did not end with $9 \mathbb{4}$, a 15 percent difference. For the $99 \$$-ending prices, the

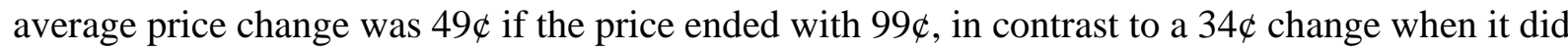
not end with 994. This is a 44 percent difference. 
With the Internet data, we considered prices ending with 9\$, 99థ, \$9, \$9.99, \$99, and \$99.99, again for the entire dataset, as well as for the low quartile of products. When we considered the entire Internet dataset, for the 9-ending prices, the average price changes were \$15.54, \$22.40, \$32.13, \$33.97, \$66.15, and \$63.04 for 9\$-, 99థ-, \$9-, \$9.99-, \$99-, and \$99.99ending prices, respectively. The corresponding non-9-ending average price changes were $\$ 18.07$, \$16.78, \$12.83, \$16.30, \$15.20, and \$16.88, respectively. In other words, the 9-ending price changes were higher than non-9-ending price changes by about -14 percent, 33 percent, 150 percent, 108 percent, 335 percent, and 273 percent, respectively. Only in one case (Notebook PCs, 9\$- vs. non-9\$-endings), was the average 9-ending price change lower than the average non-9-ending price change. See Table R22 in supplementary appendix.

When we considered the low quartile data, for 9-ending prices, the average price changes were \$24.02, \$27.78, \$11.93, \$22.47, \$49.61, and \$38.24 for the 9\$-, 99\$-, \$9-, \$9.99-, \$99-, and \$99.99-ending prices, respectively. The corresponding non-9-ending average price changes were \$21.03, \$20.76, \$7.21, \$7.38, \$18.27, and \$19.21, respectively. Thus, the 9-ending price changes for the low quartile products were higher than non-9-ending price changes by about 14 percent, 34 percent, 65 percent, 204 percent, 172 percent, and 99 percent, respectively.

Thus, the average size of the $9 \$$-ending and $99 \$$-ending price changes systematically exceed the average size of the non-9\$-ending and non-99\$-ending price changes, respectively. The fact that the results are similar for the overall data and the products in the low quartile suggests that in terms of the $9 \mathbb{\leftarrow}$ use, the difference is unlikely to be driven by product-specific effects that could simultaneously increase the prevalence of 9-ending prices and the magnitude of the price changes. If that were the case, we should not have observed larger price changes for 9-ending and 99-ending prices in the low quartile of products for which 9-ending prices are less 
common. These findings are consistent with our predictions: since 9-ending and 99-ending prices are less likely to change, the average sizes of the changes of the 9-ending and 99-ending prices are systematically larger when they do change, in comparison to the non-9-ending and non-99ending prices, respectively.

\section{Robustness}

To explore the robustness of the findings, we conducted several additional analyses, much of them following the referees' comments and suggestions. The findings we have reported for the Dominick's data were based on the analysis of the price data from the chain's four stores. We, however, have also analyzed the data for each of the four sampled stores individually, as well as the chain's entire dataset which include the price information from all 93 stores. In each case, we have considered the data for all 27 categories combined, as well as for each individual product category. For the Internet data, we have primarily reported the results of the aggregate data analysis. However, most of the analyses were repeated for each product category. In general, the results of these additional analyses are similar to the results that we have reported. Here we offer some details about these analyses and the findings. More detailed presentation of these analyses is included in the supplementary appendix.

\section{A. Evidence on the Frequency Distribution of 9- and 99-Ending Prices}

We found that $9 \$$ - and $99 \$$-ending prices were more popular than other endings at the Dominick's data (for all 93 stores combined), and at each one of the four individual stores sampled. At the category level, we found that $9 \$$-ending prices were more popular than other endings at all 27 product categories, while $99 \$$-ending prices were more popular than other endings in 23 of the 27 product categories. 
For the Internet data, we found that $9 \$$-ending and $99 \$$-ending prices were more popular than other endings for four product categories, while the $0 \$$-ending was the most popular for the remaining six categories. For the dollar digit, 9-endings were more popular than other endings in 8 of the 10 categories. For the last two dollar digits, \$99-ending prices were more popular than the other price-endings in 6 of the 10 categories. $^{8}$

We have also considered the possibility that the use of 9- and 99-ending prices is related to the sales volume. The analysis of 9- and 99-ending prices by sales volume, however, suggests no such systematic relationship. The results suggest that 9-ending prices are popular for both products that have a large sales volume and products that have a small sales volume.

\section{B. Evidence on the Frequency Distribution of Price Changes}

Similar to the other results that we have reported in this paper, we found that for regular prices in each of the four Dominick's stores, as well as for all 93 stores combined and for all prices, "9"-to-"9" was the most popular price change. For example, 37.74 percent of the

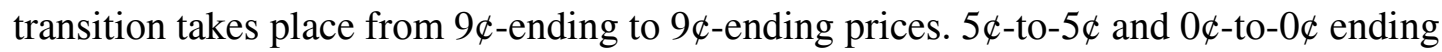
transitions only occur with 0.90 percent and 0.66 percent probabilities. The $9 \$$-ending prices are the most persistent if we consider the entire Dominick's data as well. "99"-to-"99" is not the most popular price change for any of the four stores, similar to the results reported earlier in the paper, but it is the most popular when all prices from all stores are considered. For the Dominick's dataset, in all but one category (Front-End Candies), there were considerably more price changes that were multiples of dimes and dollars for 9-ending prices.

For the Internet data, in the low-priced product categories, we found considerably more price changes that were multiples of dimes and dollars for 9-ending prices. For high-priced 
product categories, we found more price changes that were multiples of $\$ 10$ and $\$ 100$ for 9ending prices.

\section{Evidence on the Link between 9- and 99-Ending Prices and Price Rigidity}

We find a strong positive link between price points and price rigidity at the level of the entire Dominick's chain, as well at each one of the four sampled stores examined. Beginning with Store \#8, we find that the probability of a change of a $9 \$$-ending and a $99 \$$-ending prices are on average 60 percent and 28 percent lower than non-9\$-ending and non-99\$-ending prices, respectively. The result holds true for most product categories: overall, in 50 of the 54 cases (27 coefficients for the $9 \$$-ending dummy and 27 coefficients for the $99 \$$-ending dummy) the coefficient of the 9-ending dummy was negative. In 48 of these 50 cases, they were statistically significant. We found similar results for the remaining 3 stores. For example, at Store \#12, the estimated coefficient was negative in 51 of the 54 cases, with 48 of them being statistically significant. At Store \#122, the estimated coefficient was negative in 53 of the 54 cases, with 50 of them being statistically significant. At Store \#133, the estimated coefficient was negative in 53 of the 54 cases, with 51 of them being statistically significant. The findings for the entire Dominick’s dataset are even stronger: all 54 estimated coefficients were negative and statistically significant.

\section{Evidence on the Link between 9- and 99-Endings and the Size of Price Changes}

In the Dominick's dataset, in 23 of the 27 categories the average price change was higher for $9 \mathbb{\$}$-ending than for non-9\$-ending prices. The findings that we obtained for the $99 \$$-ending prices are even stronger. In 26 categories (the exception is Frozen Entries), the average change 
was higher for $99 \$$-ending than for non-99\$-ending prices. Similarly, when we focused on the low quartile of products in terms of the popularity of 9-ending prices, we found that in 21 categories the average change was higher for $9 \$$-ending than for non-9\$-ending prices. For the 99\$-ending prices, in 25 categories the average price change was higher for the 99\$-ending than for non-99\$-ending prices.

With the Internet data, we considered prices ending with 9థ, 99థ, \$9, \$9.99, \$99, and \$99.99, again for the entire dataset, as well as for the low quartile of products. For the entire dataset we find that the average price change was higher if the price ended with 9 in comparison to non-9 ending prices in $8,9,9,9,8$, and 7 categories for $94,99 \notin, \$ 9, \$ 9.99$, $\$ 99$, and $\$ 99.99$ ending prices, respectively. ${ }^{9}$ Thus, in 50 of the 56 cases, the average size of the price change was higher if the price ended with a 9-ending price point in comparison to non-9\$-ending prices.

The results for the low quartile of products are similar. Specifically, we find that the average price change was higher if the price ended with 9 in comparison to non-9 ending prices in $7,10,9,9,6$, and 6 categories for $94,99 \$, \$ 9, \$ 9.99$, $\$ 99$, and $\$ 99.99$ ending prices, respectively. ${ }^{10}$ Overall, in 47 of the 54 cases the average size of the price change was higher if the price ended with a 9-ending price point than with a non-9-ending price.

\section{Conclusion}

To our knowledge, this is the first study that directly examines the effect of price points on price rigidity across a broad range of product categories, price levels, and retailers, in the traditional retailing and the Internet-based selling formats, using data from the U.S. We found that 9-ending prices were the most popular and were less likely to change compared to non-9ending prices. Further, the most common price changes preserve the terminal digits at " 9 " and 
the size of the price changes was larger for these 9-ending prices than for non-9-ending prices. We also discovered that there is a shift in this preservation of 9-ending prices with the price level: for more expensive product categories we saw less frequent persistence of 9's in the penny and the dime digits, but more frequent persistence of 9's in the dollar, $\$ 10$, and $\$ 100$ digits.

Overall, we find that for the Dominick’s data 9-ending prices are at least 43-66 percent less likely to change than non-9-ending prices. For the Internet data, these probabilities are in the range of 25-64 percent. These figures seem to us quite substantial. We conclude therefore, that 9-ending and 99-ending prices form a considerable barrier to price changes, offering direct evidence on the link between price points and price rigidity. Combining this with the robustness of the findings - occurring in both datasets, across a wide range of product categories with a wide range of prices, products, retail formats and retailers, suggests that price points might be substantial enough to have broader macro implications. This is reinforced by the finding that the use of 9s shifts leftwards as the products' average price increases, which suggest that the phenomenon of 9-ending prices rigidity may exist in markets for other goods and services in more expensive product categories where the use of 9-endings in $\$ 1, \$ 10, \$ 100$ digits, etc. is quite common. These include prices of the goods sold at department stores such as clothes, shoes, fragrances, jewelry, and high tech equipment, as well as other high priced products and services such as musical instruments, furniture, cars, home appliances, hotels, air travel, car rentals, and even in pricing of homes and apartments. Taken together, these goods and services comprise a substantial proportion of the aggregate consumption and thus may have a considerable economic significance.

The use of 9-ending prices seems to be relevant in the context of public policy issues as well. For example, the use of 9-ending prices is often debated in countries where low- 
denomination coins have been abolished. When small denomination coins are no longer used, transactions involving small changes must rely on rounding, as is the case in Israel, Hungary, or Singapore. In Israel, for example, the 1-Agora coin was abolished in 1991, and the 5-Agora coin was eliminated in 2008. The law, therefore, requires that the final bills be rounded up (if it ends with 5-Agora-9-Agora) or down (if it ends with 1-Agora-4-Agora) to the nearest 10-Agora. It turns out, however, that the Israeli retailers use 9-ending prices extensively, which irritates consumers, who claim that 9-ending prices are unethical given the absence of 1-Agora coin. The Israeli Parliament has twice rejected a proposed law which would outlaw the use of 9-ending prices. ${ }^{11}$ This may extend to other countries soon. For example, dropping the smallest currency unit has been a recent topic of debate in the U.S., Canada and Europe ${ }^{12}$. Australia has stopped issuing $1 \mathbb{\leftarrow}$ and $2 \mathbb{C}$ coins in 1989 . New Zealand ceased issuing the $1 \mathbb{\complement}$ and $2 \mathbb{\leftarrow}$ coins in 1989. Denmark stopped issuing the 5- and 10-ores in 1989. The Dutch eliminated the $1 \$$ of the guilder in 1980 and ceased issuing the $1 \mathbb{\$}$ and $2 \mathbb{\$}$ of Dutch euro coins in 2006. In Finland, the $1 \nsubseteq$ and $2 \$$ of Finnish euro coins are not in general use any longer. In 2008, Hungary eliminated the 1 and 2 forint coins. France, Norway, Britain and Singapore have also eliminated lowdenomination coins.

The common use of price points has also received considerable attention in some European Union countries in the context of the conversion of prices from local currencies to the euro. The concern has been about the possibility that retailers may have acted opportunistically by rounding their prices upward after conversion to the euro in their attempt to preserve the price points. This appears to be true, for example, in the case of products that are sold through automated devices, such as soda and candy bar vending machines, parking meters, coin-operated laundry machines, etc. (Bils and Klenow 2004, Levy and Young 2004, and Campbell and Eden 
2010, Ehrmann 2010, Hoffmann and Kurz-Kim 2009).

In our data, 9 is the most popular terminal digit overall. The use of price points, however, seems to vary across countries. For example, Konieczny and Rumler (2007) and Konieczny and Skrzypacz (2010) note that 9-ending prices are particularly popular in the U.S., Canada, Germany, and Belgium, but they are rare in Spain, Italy, Poland, and Hungary. According to Heeler and Nguyen (2001), in the Chinese culture, numbers have special significance and symbolism. The number 8, for example, is associated with "success." ${ }^{\text {"13 }}$ They find that close to 50 percent of restaurant menu prices sampled in Hong Kong had 8-endings, which they refer to as "happy endings.” Also, a Time Magazine article (Rawe, 2004) reports that at the casino of the recently-built \$240 million Sands Macao hotel in Macao, China, the slot machines’ winning trios of 7's have been replaced with trios of 8's. Consistent with these observations, the opening ceremony of the Beijing Olympic Games, held in the Beijing National Stadium, began exactly at 08:08:08 p.m. on 8/8/2008 ${ }^{14}$.

Knotek $(2008,2010)$ has focused on other types of pricing practices, especially the common use of round prices, which he terms "convenient prices” because their use reduces the amount of the change used in a transaction. Levy and Young $(2004,2008)$ reported that the nominal price of Coca Cola was fixed for almost 70 years at $5 \$$, also a convenient price.

Future work might study such pricing practices across other products, industries, retailers, and countries to assess the generalizability of these findings and observations. Beyond documenting these facts, this study raises interesting questions concerning the importance of price points for monetary non-neutrality. For example, how much monetary non-neutrality could be generated by pricing points? How are pricing points determined? To answer these questions, one would need a monetary economy model with pricing points. These remain interesting 
avenues for future research.

We end by noting that the Internet provides a unique context for micro-level studies of price setting behavior (Bergen et al. 2005). The ability to access transaction price data using software agents has allowed us to explore pricing and price adjustment patterns at a low cost and with a previously unimaginable level of microeconomic detail. This approach also allows empirical research methods to take advantage of natural experiments in the real world (Kauffman and Wood, 2007, 2009). With the expanding retail activities on the Internet, and new techniques and tools that have become available, we expect such opportunities to increase further in the future. 


\section{References}

Alvarez, F.E., F. Lippi, and L. Paciello (2010), “Optimal Price Setting with Observation and Menu Costs," NBER Working Paper, Number 15852, Cambridge, MA.

Ball, L. and D. Romer (2003), "Inflation and the Informativeness of Prices,” Journal of Money, Credit and Banking 35(2), 177-196.

Barsky, R., Bergen, M., Dutta, S. and Levy, D. (2003), “What Can the Price Gap between Branded and Private Label Products Tell Us about Markups?” in R. Feenstra and M. Shapiro (eds.), Scanner Data and Price Indexes (Chicago, IL: University of Chicago Press), 165-225.

Bergen M., R. J. Kauffman, and D. Lee (2005), “Beyond the Hype of Frictionless Markets: Evidence of Heterogeneity in Price Rigidity on the Internet,” Journal of Management Information Systems 22(2), 57-89.

Bergen, M., D. Levy, S. Ray, P. Rubin, and B. Zeliger (2008), “On the Inefficiency of Item Pricing Laws: Theory and Evidence,” Journal of Law and Economics 51(2), 209-250.

Besley, T. and H. Rosen (1999), “Sales Taxes and Prices: an Empirical Analysis,” National Tax Journal 52(2), 157-178.

Bils, M. and P. Klenow (2004), “Some Evidence on the Importance of Sticky Prices,” Journal of Political Economy 112(5), 947-985.

Bizer, G. and R. Schindler (2005), “Direct Evidence of Ending-Digit Drop-Off in Price Information Processing,” Psychology and Marketing 22(10), 771-783.

Blinder, A. S., R. Elie, D. Canetti, D. Lebow, and J. Rudd (1998), Asking About Prices: A New Approach to Understanding Price Stickiness (New York, NY: Russell Sage Foundation).

Campbell, J. and B. Eden (2010), “Rigid Prices: Evidence from U.S. Scanner Data,” Working Paper No. 2005-08, Federal Reserve Bank of Chicago, Chicago, IL. 
Carlton, D. W. (1986), “The Rigidity of Prices,” American Economic Review 76(4), 637-658.

Cecchetti, S. (1986), “The Frequency of Price Adjustment: A Study of the Newsstand Prices of Magazines,” Journal of Econometrics 31(3), 255-274.

Chen, H., D. Levy, S. Ray and M. Bergen (2008), “Asymmetric Price Adjustment in the Small,” Journal of Monetary Economics 55(4), 728-737.

Chevalier, J., A. Kashyap, and P. Rossi (2003), “Why Don’t Prices Rise during Periods of Peak Demand? Evidence from Scanner Data,” American Economic Review 93(1), 15-37.

Danziger, L. (1999), "A Dynamic Economy with Costly Price Adjustments," American Economic Review 89(4), 878-901.

Danziger, L. (2007), "Output Effects of Inflation with Fixed Price- and Quantity-Adjustment Costs," Economic Inquiry 45(1), 115-120.

Dutta, S., M. Bergen, D. Levy, and R. Venable (1999), “Menu Costs, Posted Prices, and Multiproduct Retailers,” Journal of Money, Credit, and Banking 31(4), 683-703.

Dutta, S., D. Levy, and M. Bergen (2002), “Price Flexibility in Channels of Distribution: Evidence from Scanner Data,” Journal of Economic Dynamics and Control 26(11), 18451900.

Ehrmann, M. (2010), “Inflation Developments and Perceptions after the Euro Cash Changeover,” German Economic Review, forthcoming.

Eichenbaum, M., N. Jaimovich, and S. Rebelo (2010), “Reference Prices, Costs and Nominal Rigidities,” American Economic Review, forthcoming.

Fabiani, S., M. Druant, I. Hernando, C. Kwapil, B. Landau, C. Loupias, F. Martins, T. Mathä, R. Sabbatini, H. Stahl, and A. Stokman (2006), “What Firms’ Surveys Tell Us about Price- 
Setting Behavior in the Euro Area: New Survey Evidence,” International Journal of Central Banking 2(3), 3-47.

Heeler, R. and A. Nguyen (2001), “Price Endings in Asia,” in B. Murphy and L. Engle (Eds.), Proceedings of Australia-New Zealand Marketing Association (Auckland, New Zealand: Massey University Press), pp. 64-71.

Hoffmann, J. and J. R. Kurz-Kim (2009), “Consumer Price Adjustment under the Microscope: Germany in a Period of Low Inflation,” Working Paper, Deutsche Bundesbank, Frankfurt, Germany.

Kashyap, A. K. (1995), “Sticky Prices: New Evidence from Retail Catalogues,” Quarterly Journal of Economics 110(1), 245-274.

Kauffman, R. J. and C. A. Wood (2007), "Follow the Leader: Price Change Timing and Strategic Pricing in E-Commerce,” Managerial and Decision Economics 28(7), 679-700.

Kauffman, R. J. and C. A. Wood (2009), "Revolutionary Research Strategies for E-Business: A Philosophy of Science View in the Age of the Internet,” in R. J. Kauffman and P. A. Tallon (Eds.), Economics, Information Systems, and Electronic Commerce Research: Advanced Empirical Methodologies (Armonk, NY: M. E. Sharpe), pp. 31-62.

Kehoe, P. and V. Midrigan (2010), “Prices Are Sticky After All,” Research Staff Report, No. 413, Federal Reserve Bank of Minneapolis, Minneapolis, MN.

Klenow, P.J. and O. Kryvtsov (2008), "State-Dependent vs. Time-Dependent Pricing: Does it Matter for Recent U.S. Inflation?” Quarterly Journal of Economics 123(3), 863-904.

Klenow, P.J. and B.A. Malin (2010), "Microeconomic Evidence on Price-Setting," in B. Friedman and M. Woodford (Eds.), Handbook of Monetary Economics (New York, NY: North Holland), forthcoming. 
Knotek, E. S., II (2008), “Convenient Prices, Currency and Nominal Rigidity: Theory with Evidence from Newspaper Prices,” Journal of Monetary Economics 55(7), 1303-1316.

Knotek, E.S., II (2010), “Convenient Prices and Price Rigidity: Cross-Sectional Evidence,” Review of Economics and Statistics, forthcoming.

Konieczny, J. (2003), “Discussant Comments [on this Paper],” Central European University Conference on Microeconomic Pricing and the Macroeconomy, Budapest, Hungary.

Konieczny, J. and F. Rumler (2007), “Regular Adjustment: Theory and Evidence,” Kiel Working Paper No. 1352, Kiel Institute for the World Economy, Kiel, Germany.

Konieczny, J. and A. Skrzypacz (2010), “Search, Costly Price Adjustment and the Frequency of Price Changes: Theory and Evidence,” manuscript, Stanford University.

Levy D., M. Bergen, S. Dutta and R. Venable (1997), “The Magnitude of Menu Costs: Direct Evidence from Large U.S. Supermarket Chains,” Quarterly Journal of Economics 112(3), 791-825.

Levy, D. and A. Young (2004), “The Real Thing: Nominal Price Rigidity of the Nickel Coke, 1886-1959,” Journal of Money, Credit and Banking 36(4), 765-799.

Levy, D., G. Müller, H. Chen, M. Bergen, and S. Dutta (2010), "Holiday Price Rigidity and Cost of Price Adjustment," Economica 77(305), 172-198.

Midrigan, V. (2010), "Menu Costs, Multi-Product Firms, and Aggregate Fluctuations," Econometrica, forthcoming.

Mirhadi, D. (2000), “Hotels Reach Overseas to Fill Beds, Restaurants, Showrooms,” Las Vegas Review-Journal, May 18, 2000. 
Nakamura, E. and J. Steinsson (2008), “Five Facts about Prices: A Reevaluation of Menu Cost Models,” Quarterly Journal of Economics 123(4), 1415-1464.

Nakamura, E. and J. Steinsson (2009), "Price Setting in Forward-Looking Customer Markets,” Manuscript, Columbia University, New York, NY.

Rotemberg, J. (1987), “The New Keynesian Microfoundations,” NBER Macro Annual, 69-104.

Rotemberg, J. (2005), “Customer Anger at Price Increases, Changes in the Frequency of Price Adjustment, and Monetary Policy,” Journal of Monetary Economics 52(4), 829-852.

Rotemberg, J. (2010), “Altruistic Dynamic Pricing with Customer Regret,” Scandinavian Journal of Economics, forthcoming.

Schindler, R. M. (2006), “The 99-Price Ending as a Signal of a Low Price Appeal,” Journal of Retailing 82(1), 71-77.

Stahl, H. (2010) “Price Adjustment in German Manufacturing: Evidence from Two Merged Surveys,” Managerial and Decision Economics 31(2-3), 67-92.

Toy, V.S. (2010), "Sometimes, Lucky Numbers Add Up to Apartment Sales," The New York Times (New York edition), October 24, 2010, page RE1.

Warner, E. and R. Barsky (1995), “The Timing and Magnitude of Retail Store Markdowns: Evidence from Weekends and Holidays,” Quarterly Journal of Economics 110(2), 321-352.

Willis, J. (2003), “Implications of Structural Changes in the U.S. Economy for Pricing Behavior and Inflation Dynamics,” Federal Reserve Bank of Kansas City Economic Review, Kansas City, MO (1 ${ }^{\text {st }}$ quarter), 5-26.

Wolman, A. L. (2007), “The Frequency and Costs of Individual Price Adjustment: A Survey,” Managerial and Decision Economics 28(6), 531-552. 
Wooldridge, J. (2002), Econometric Analysis of Cross Section and Panel Data (Cambridge, MA: MIT Press). 
Table 1. Descriptive Statistics for the Dominick’s Price Data,

Stores \#8, \#12, \#122 and \#133

\begin{tabular}{|l|c|c|c|c|c|r|}
\hline Category & $\begin{array}{c}\text { Number of } \\
\text { Observations }\end{array}$ & $\begin{array}{c}\text { Number of } \\
\text { Products }\end{array}$ & $\begin{array}{c}\text { Mean } \\
\text { Price }\end{array}$ & $\begin{array}{c}\text { Std. } \\
\text { Dev. }\end{array}$ & $\begin{array}{c}\text { Min. } \\
\text { Price }\end{array}$ & $\begin{array}{c}\text { Max. } \\
\text { Price }\end{array}$ \\
\hline Analgesics & 174,132 & 599 & $\$ 5.32$ & $\$ 2.51$ & $\$ 0.47$ & $\$ 23.69$ \\
\hline Bath Soap & 31,859 & 492 & $\$ 3.31$ & $\$ 1.76$ & $\$ 0.47$ & $\$ 18.99$ \\
\hline Bathroom Tissue & 52,856 & 119 & $\$ 2.14$ & $\$ 1.71$ & $\$ 0.25$ & $\$ 11.99$ \\
\hline Beer & 126,295 & 595 & $\$ 5.69$ & $\$ 2.69$ & $\$ 0.99$ & $\$ 26.99$ \\
\hline Bottled Juice & 204,967 & 460 & $\$ 2.24$ & $\$ 0.97$ & $\$ 0.32$ & $\$ 8.00$ \\
\hline Canned Soup & 251,505 & 400 & $\$ 1.15$ & $\$ 0.49$ & $\$ 0.23$ & $\$ 5.00$ \\
\hline Canned Tuna & 111,142 & 247 & $\$ 1.82$ & $\$ 1.07$ & $\$ 0.25$ & $\$ 11.19$ \\
\hline Cereals & 213,771 & 447 & $\$ 3.17$ & $\$ 0.78$ & $\$ 0.29$ & $\$ 7.49$ \\
\hline Cheeses & 312,455 & 594 & $\$ 2.43$ & $\$ 1.12$ & $\$ 0.10$ & $\$ 11.50$ \\
\hline Cigarettes & 80,637 & 599 & $\$ 8.23$ & $\$ 8.40$ & $\$ 0.89$ & $\$ 25.65$ \\
\hline Cookies & 355,388 & 1,018 & $\$ 2.11$ & $\$ 0.63$ & $\$ 0.25$ & $\$ 8.79$ \\
\hline Crackers & 107,527 & 290 & $\$ 2.03$ & $\$ 0.57$ & $\$ 0.25$ & $\$ 6.85$ \\
\hline Dish Detergent & 101,077 & 270 & $\$ 2.37$ & $\$ 0.92$ & $\$ 0.39$ & $\$ 7.00$ \\
\hline Fabric Softeners & 108,050 & 308 & $\$ 2.85$ & $\$ 1.47$ & $\$ 0.10$ & $\$ 9.99$ \\
\hline Front-End-Candies & 208,322 & 443 & $\$ 0.61$ & $\$ 0.24$ & $\$ 0.01$ & $\$ 6.99$ \\
\hline Frozen Dinners & 84,942 & 239 & $\$ 2.35$ & $\$ 0.88$ & $\$ 0.28$ & $\$ 9.99$ \\
\hline Frozen Entrees & 340,123 & 825 & $\$ 2.31$ & $\$ 1.06$ & $\$ 0.25$ & $\$ 15.99$ \\
\hline Frozen Juices & 109,916 & 160 & $\$ 1.36$ & $\$ 0.43$ & $\$ 0.22$ & $\$ 5.00$ \\
\hline Grooming Products & 244,043 & 1,237 & $\$ 2.95$ & $\$ 1.39$ & $\$ 0.49$ & $\$ 11.29$ \\
\hline Laundry Detergents & 156,156 & 556 & $\$ 5.67$ & $\$ 3.24$ & $\$ 0.39$ & $\$ 24.49$ \\
\hline Oatmeal & 47,584 & 94 & $\$ 2.66$ & $\$ 0.67$ & $\$ 0.49$ & $\$ 5.00$ \\
\hline Paper Towels & 43,389 & 150 & $\$ 1.55$ & $\$ 1.51$ & $\$ 0.33$ & $\$ 12.59$ \\
\hline Refrigerated Juices & 102,221 & 213 & $\$ 2.20$ & $\$ 0.88$ & $\$ 0.39$ & $\$ 7.05$ \\
\hline Shampoos & 306,053 & 2,615 & $\$ 3.06$ & $\$ 1.87$ & $\$ 0.27$ & $\$ 29.99$ \\
\hline Snack Crackers & 163,346 & 390 & $\$ 2.19$ & $\$ 0.59$ & $\$ 0.10$ & $\$ 8.00$ \\
\hline Soaps & 94,722 & 313 & $\$ 2.60$ & $\$ 1.58$ & $\$ 0.25$ & $\$ 9.99$ \\
\hline Soft Drinks & 516,692 & 1,411 & $\$ 2.35$ & $\$ 1.90$ & $\$ 0.10$ & $\$ 26.02$ \\
\hline Toothbrushes & 99,921 & 447 & $\$ 2.24$ & $\$ 0.93$ & $\$ 0.39$ & $\$ 9.99$ \\
\hline Toothpastes & 161,038 & 574 & $\$ 2.49$ & $\$ 0.97$ & $\$ 0.31$ & $\$ 10.99$ \\
\hline Total & $4,910,129$ & 16,105 & $\$ 2.67$ & $\$ 2.22$ & $\$ 0.01$ & $\$ 29.99$ \\
\hline \hline Note: The & & & & & & \\
\hline
\end{tabular}

Note: The data are weekly. The sampled stores belong to four price tiers as follows: Store \#8 - "low” price tier, \#12 - "high” price tier, \#122 - “Cub Fighter," and \#133 "medium" price tier. See section II for details. 
Table 2. Descriptive Statistics for the Internet Price Data

\begin{tabular}{|l|c|c|c|c|c|r|r|}
\hline Category & $\begin{array}{c}\text { Number of } \\
\text { Observations }\end{array}$ & $\begin{array}{c}\text { Number of } \\
\text { Products }\end{array}$ & $\begin{array}{c}\text { Number of } \\
\text { Retailers }\end{array}$ & $\begin{array}{c}\text { Mean } \\
\text { Price }\end{array}$ & $\begin{array}{c}\text { Std. } \\
\text { Dev. }\end{array}$ & $\begin{array}{c}\text { Min. } \\
\text { Price }\end{array}$ & $\begin{array}{c}\text { Max. } \\
\text { Price }\end{array}$ \\
\hline Music CDs & 302,914 & 46 & 15 & $\$ 13.46$ & $\$ 3.50$ & $\$ 3.99$ & $\$ 26.98$ \\
\hline Movie DVDs & 447,519 & 49 & 22 & $\$ 27.42$ & $\$ 26.70$ & $\$ 4.95$ & $\$ 144.99$ \\
\hline Video Games & 244,625 & 49 & 38 & $\$ 30.83$ & $\$ 12.57$ & $\$ 4.90$ & $\$ 57.99$ \\
\hline Software & 382,297 & 48 & 83 & $\$ 294.07$ & $\$ 417.60$ & $\$ 4.95$ & $\$ 5,695.00$ \\
\hline Hard Drives & 263,244 & 46 & 73 & $\$ 330.67$ & $\$ 556.29$ & $\$ 39.00$ & $\$ 3,670.98$ \\
\hline PDAs & 148,731 & 45 & 92 & $\$ 346.60$ & $\$ 193.24$ & $\$ 32.99$ & $\$ 956.95$ \\
\hline DVD Players & 220,236 & 49 & 104 & $\$ 369.51$ & $\$ 247.75$ & $\$ 57.99$ & $\$ 1,489.00$ \\
\hline PC Monitors & 319,369 & 51 & 87 & $\$ 682.89$ & $\$ 659.13$ & $\$ 85.78$ & $\$ 3,010.41$ \\
\hline $\begin{array}{l}\text { Digital Cameras } \\
\text { Notebook PCs }\end{array}$ & 247,917 & 46 & 143 & $\$ 760.12$ & $\$ 688.76$ & $\$ 175.95$ & $\$ 6,000.00$ \\
\hline
\end{tabular}


Table 3. Top 10 Highest Frequencies in the Internet Data

\begin{tabular}{|c|c|c|c|c|}
\hline Rank & $\begin{array}{l}\text { Last } 3 \text { Digits of } \\
\text { Price Endings }\end{array}$ & $\begin{array}{l}\text { Last } 4 \text { Digits of } \\
\text { Price Endings }\end{array}$ & Price Changes & $\begin{array}{c}\text { Price Changes with } \\
\text { Three Categories } \\
\text { Left Out }\end{array}$ \\
\hline 1 & & & & \\
\hline 2 & $\mathbf{\$ 9 . 0 0}(9.98 \%)$ & $\$ 99.00(3.46 \%)$ & $\$ 2.00$ (4.49\%) & \\
\hline 3 & $(4.86 \%)$ & $\$ 19$ & $\$ 10.00$ (3.24\%) & $\$ 10$. \\
\hline 4 & & & & \\
\hline 5 & $\$ 5.00(2.48 \%)$ & $\$ 29.9$ & & \\
\hline 6 & & $\$ 49.0$ & & \\
\hline 7 & $\$ 8.9$ & $\$ 14$ & $\$ 20$ & $\$ 20$ \\
\hline 8 & $\$ 8.0$ & $\$ 99.95$ (1.09\%) & $0(1.55 \%)$ & $\$ 6.00(2.18 \%)$ \\
\hline 9 & & $\$ 09.99(0.97 \%)$ & & \\
\hline 10 & $\$ 4.95(1.42 \%)$ & $\$ 79.00(0.87 \%)$ & $\$ 0.01(1.38 \%)$ & $\$ 7.00(1.47 \%)$ \\
\hline \multicolumn{5}{|c|}{$\begin{array}{l}\text { Note: The figures in each column are ordered from the most frequent to the leas } \\
\text { frequent. Bold-marked prices in the first three rows indicate that they are in the top three } \\
\text { most frequent in each category. The right-most column shows the top ten most frequen } \\
\text { price changes after three product categories (Music CDs, Movie DVDs, and Videc } \\
\text { Games) are excluded from the analysis. }\end{array}$} \\
\hline
\end{tabular}


Table 4. Transition Probability Matrix Conditional on a Price Change for a 10-State

Markov Chain, Dominick’s Data, Stores \#8, \#12, \#122, \#133, Regular Prices Only, for the

\section{Penny Digit}

\begin{tabular}{|c|c|c|c|c|c|c|c|c|c|c|c|}
\hline & \multicolumn{10}{|c|}{ Next Period Ending Digit (\$) } \\
\hline & & $\mathbf{0}$ & 1 & 2 & 3 & 4 & 5 & 6 & 7 & 8 & 9 \\
\hline \multirow{10}{*}{ 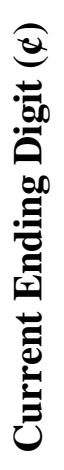 } & $\mathbf{0}$ & 0.64 & 0.25 & 0.29 & 0.31 & 0.33 & 0.79 & 0.26 & 0.23 & 0.16 & 3.68 \\
\hline & 1 & 0.26 & 0.14 & 0.18 & 0.21 & 0.14 & 0.44 & 0.14 & 0.13 & 0.09 & 2.98 \\
\hline & 2 & 0.25 & 0.13 & 0.15 & 0.18 & 0.19 & 0.36 & 0.18 & 0.15 & 0.09 & 1.81 \\
\hline & 3 & 0.28 & 0.20 & 0.16 & 0.33 & 0.22 & 0.47 & 0.20 & 0.24 & 0.15 & 2.47 \\
\hline & 4 & 0.30 & 0.12 & 0.17 & 0.18 & 0.29 & 0.40 & 0.23 & 0.17 & 0.11 & 2.93 \\
\hline & 5 & 0.72 & 0.30 & 0.32 & 0.42 & 0.33 & 0.84 & 0.43 & 0.49 & 0.26 & 3.81 \\
\hline & 6 & 0.26 & 0.15 & 0.18 & 0.21 & 0.26 & 0.37 & 0.20 & 0.29 & 0.14 & 2.15 \\
\hline & 7 & 0.23 & 0.14 & 0.15 & 0.28 & 0.21 & 0.41 & 0.25 & 0.24 & 0.13 & 2.17 \\
\hline & 8 & 0.15 & 0.10 & 0.11 & 0.14 & 0.14 & 0.29 & 0.13 & 0.13 & 0.12 & 1.43 \\
\hline & 9 & 3.40 & 1.58 & 1.45 & 1.88 & 2.34 & 3.15 & 1.85 & 1.77 & 0.85 & 37.87 \\
\hline
\end{tabular}

Note: Each cell contains the percentage of the price change compared to the total price change (i.e., 1,374,142). The top three highest transition probabilities on the matrix diagonal are indicated in boldface. 
Table 5. Transition Probability Matrix Conditional on a Price Change for a 10-State Markov Chain, Internet Data, for the Penny Digit

\begin{tabular}{|c|c|c|c|c|c|c|c|c|c|c|c|}
\hline & \multicolumn{10}{|c|}{ Next Period Ending Digit (\$) } \\
\hline & & 0 & 1 & 2 & 3 & 4 & 5 & 6 & 7 & 8 & 9 \\
\hline \multirow{10}{*}{ 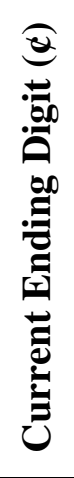 } & 0 & 20.35 & 0.35 & 0.35 & 0.34 & 0.33 & 1.40 & 0.39 & 0.38 & 0.52 & 1.69 \\
\hline & 1 & 0.32 & 0.39 & 0.33 & 0.32 & 0.34 & 0.29 & 0.30 & 0.28 & 0.30 & 0.40 \\
\hline & 2 & 0.40 & 0.33 & 0.47 & 0.34 & 0.34 & 0.27 & 0.24 & 0.31 & 0.34 & 0.32 \\
\hline & 3 & 0.34 & 0.29 & 0.32 & 0.47 & 0.33 & 0.35 & 0.32 & 0.30 & 0.41 & 0.43 \\
\hline & 4 & 0.37 & 0.34 & 0.37 & 0.31 & 0.66 & 0.52 & 0.40 & 0.38 & 0.37 & 0.87 \\
\hline & 5 & 1.45 & 0.33 & 0.30 & 0.34 & 0.48 & 10.63 & 0.45 & 0.34 & 0.53 & 2.04 \\
\hline & 6 & 0.34 & 0.29 & 0.31 & 0.34 & 0.43 & 0.48 & 0.86 & 0.41 & 0.30 & 0.66 \\
\hline & 7 & 0.39 & 0.27 & 0.27 & 0.37 & 0.36 & 0.32 & 0.33 & 0.66 & 0.49 & 0.58 \\
\hline & 8 & 0.54 & 0.33 & 0.30 & 0.37 & 0.44 & 0.58 & 0.41 & 0.48 & 2.95 & 1.21 \\
\hline & 9 & 1.54 & 0.42 & 0.42 & 0.48 & 0.87 & 2.19 & 0.54 & 0.56 & 1.47 & 17.68 \\
\hline \multicolumn{12}{|c|}{$\begin{array}{l}\text { Note: Each cell contains the percentage of the price changes compared to the } \\
\text { total number of price changes }(41,034) \text {. The top three highest transition } \\
\text { probabilities on the matrix diagonal are indicated in boldface. }\end{array}$} \\
\hline
\end{tabular}


Table 6. Transition Probability Matrix Conditional on a Price Change for a 10-State Markov Chain, Internet Data, for the Dollar Digit

\begin{tabular}{|c|c|c|c|c|c|c|c|c|c|c|c|}
\hline & \multicolumn{10}{|c|}{ Next Period Ending Digit (\$) } \\
\hline & & 0 & 1 & 2 & 3 & 4 & 5 & 6 & 7 & 8 & 9 \\
\hline \multirow{10}{*}{ 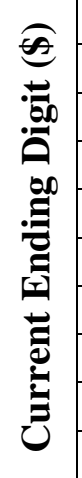 } & $\mathbf{0}$ & 1.58 & 0.85 & 0.45 & 0.40 & 0.42 & 0.43 & 0.35 & 0.41 & 0.68 & 1.38 \\
\hline & $\mathbf{1}$ & 0.98 & 2.18 & 1.06 & 0.49 & 0.40 & 0.35 & 0.33 & 0.40 & 0.43 & 0.97 \\
\hline & 2 & 0.58 & 1.19 & 1.72 & 1.01 & 0.76 & 0.56 & 0.34 & 0.32 & 0.48 & 1.12 \\
\hline & 3 & 0.46 & 0.67 & 1.23 & 1.99 & 1.12 & 0.65 & 0.50 & 0.42 & 0.51 & 1.00 \\
\hline & 4 & 0.55 & 0.49 & 0.87 & 1.30 & 2.73 & 1.32 & 0.69 & 0.65 & 0.62 & 1.98 \\
\hline & 5 & 0.49 & 0.44 & 0.61 & 0.90 & 1.50 & 2.52 & 1.01 & 0.67 & 0.54 & 1.45 \\
\hline & 6 & 0.36 & 0.37 & 0.42 & 0.52 & 0.88 & 1.15 & 1.47 & 0.86 & 0.64 & 1.04 \\
\hline & 7 & 0.33 & 0.30 & 0.41 & 0.48 & 0.79 & 0.79 & 1.14 & 1.27 & 0.88 & 1.22 \\
\hline & 8 & 0.49 & 0.39 & 0.38 & 0.57 & 0.56 & 0.72 & 0.71 & 1.11 & 1.73 & 1.79 \\
\hline & 9 & 1.08 & 0.83 & 0.81 & 0.91 & 1.98 & 1.56 & 1.25 & 1.47 & 2.09 & 11.75 \\
\hline \multicolumn{12}{|c|}{$\begin{array}{l}\text { Note: Each cell contains the percentage of the price changes compared to the } \\
\text { total number of price changes }(41,034) \text {. The top three highest transition } \\
\text { probabilities on the matrix diagonal are indicated in boldface. }\end{array}$} \\
\hline
\end{tabular}


Table 7. Top 25 Transition Probabilities Conditional on a Price Change for a 100-State Markov Chain, Dominick’s Data, by Store, Regular Prices Only, for the Penny and Dime Digits

\begin{tabular}{|c|c|c|c|c|c|c|c|c|c|c|c|c|}
\hline \multirow[b]{2}{*}{ Rank } & \multicolumn{3}{|c|}{ Store 8} & \multicolumn{3}{|c|}{ Store 12} & \multicolumn{3}{|c|}{ Store 122} & \multicolumn{3}{|c|}{ Store 133} \\
\hline & $\begin{array}{c}\text { Curre } \\
\text { nt } \\
\text { Endin } \\
\text { g } \\
\end{array}$ & $\begin{array}{c}\text { Next } \\
\text { Endi } \\
\text { ng }\end{array}$ & $\%$ & $\begin{array}{c}\text { Curre } \\
\text { nt } \\
\text { Endin } \\
\text { g } \\
\end{array}$ & $\begin{array}{l}\text { Next } \\
\text { Endin } \\
\quad \mathbf{g}\end{array}$ & $\%$ & $\begin{array}{c}\text { Cur } \\
\text { rent } \\
\text { End } \\
\text { ing }\end{array}$ & $\begin{array}{c}\text { Next } \\
\text { Endi } \\
\text { ng }\end{array}$ & $\%$ & $\begin{array}{c}\text { Curr } \\
\text { ent } \\
\text { Endi } \\
\text { ng }\end{array}$ & $\begin{array}{c}\text { Next } \\
\text { Endi } \\
\text { ng }\end{array}$ & $\%$ \\
\hline 1 & 89 & 99 & 1.34 & 89 & 99 & 1.09 & 89 & 99 & 0.87 & 89 & 99 & 0.82 \\
\hline 2 & 99 & 89 & 1.03 & 99 & 89 & 0.86 & 99 & 89 & 0.70 & 39 & 49 & 0.65 \\
\hline 3 & 99 & 19 & 0.86 & 79 & 99 & 0.83 & 99 & 19 & 0.61 & 79 & 89 & 0.62 \\
\hline 4 & 39 & 49 & 0.79 & 79 & 89 & 0.71 & 79 & 89 & 0.58 & 99 & 19 & 0.61 \\
\hline 5 & 79 & 99 & 0.78 & 99 & 19 & 0.70 & 79 & 99 & 0.58 & 79 & 99 & 0.60 \\
\hline 6 & 49 & 99 & 0.75 & 99 & 49 & 0.69 & 39 & 49 & 0.57 & 99 & 29 & 0.60 \\
\hline 7 & 79 & 89 & 0.73 & 59 & 99 & 0.68 & 29 & 39 & 0.55 & 99 & 89 & 0.60 \\
\hline 8 & 99 & 49 & 0.73 & 99 & 29 & 0.68 & 99 & 09 & 0.55 & 99 & 09 & 0.54 \\
\hline 9 & 99 & 29 & 0.72 & 49 & 99 & 0.67 & 99 & 29 & 0.50 & 29 & 39 & 0.53 \\
\hline 10 & 19 & 99 & 0.71 & 99 & 59 & 0.64 & 69 & 99 & 0.49 & 49 & 99 & 0.50 \\
\hline 11 & 99 & 09 & 0.70 & 99 & 79 & 0.63 & 19 & 29 & 0.48 & 49 & 59 & 0.48 \\
\hline 12 & 29 & 99 & 0.70 & 99 & 99 & 0.61 & 19 & 99 & 0.47 & 29 & 99 & 0.47 \\
\hline 13 & 99 & 99 & 0.66 & 49 & 59 & 0.59 & 59 & 69 & 0.46 & 19 & 29 & 0.45 \\
\hline 14 & 29 & 39 & 0.60 & 29 & 99 & 0.58 & 49 & 99 & 0.45 & 59 & 69 & 0.45 \\
\hline 15 & 99 & 79 & 0.60 & 39 & 49 & 0.56 & 99 & 99 & 0.43 & 19 & 99 & 0.44 \\
\hline 16 & 99 & 39 & 0.55 & 19 & 99 & 0.55 & 99 & 49 & 0.42 & 69 & 99 & 0.44 \\
\hline 17 & 69 & 99 & 0.53 & 29 & 39 & 0.54 & 29 & 99 & 0.42 & 99 & 49 & 0.44 \\
\hline 18 & 69 & 79 & 0.52 & 59 & 69 & 0.52 & 69 & 79 & 0.42 & 99 & 99 & 0.43 \\
\hline 19 & 49 & 59 & 0.51 & 99 & 09 & 0.52 & 99 & 79 & 0.41 & 69 & 79 & 0.42 \\
\hline 20 & 09 & 19 & 0.50 & 69 & 99 & 0.50 & 49 & 59 & 0.40 & 09 & 19 & 0.41 \\
\hline 21 & 19 & 29 & 0.50 & 69 & 79 & 0.49 & 99 & 39 & 0.40 & 99 & 79 & 0.39 \\
\hline 22 & 59 & 69 & 0.49 & 09 & 19 & 0.48 & 09 & 99 & 0.40 & 29 & 49 & 0.36 \\
\hline 23 & 09 & 99 & 0.49 & 19 & 29 & 0.45 & 09 & 19 & 0.38 & 59 & 99 & 0.35 \\
\hline 24 & 99 & 69 & 0.48 & 99 & 39 & 0.43 & 99 & 69 & 0.37 & 94 & 99 & 0.33 \\
\hline 25 & 39 & 99 & 0.46 & 99 & 69 & 0.42 & 39 & 29 & 0.35 & 99 & 69 & 0.32 \\
\hline
\end{tabular}


Table 8. Top 25 Transition Probabilities Conditional on a Price Change for a 100-State Markov Chain, Internet Dataset, for the Penny and Dime Digits (LHS) and for the Dollar and \$10 Digits (RHS)

\begin{tabular}{|c|c|c|r||c|c|c|}
\hline & \multicolumn{3}{|c|}{ Cents } & \multicolumn{3}{c|}{ Dollars } \\
\cline { 2 - 7 } Rank & $\begin{array}{c}\text { Current } \\
\text { Ending }\end{array}$ & $\begin{array}{c}\text { Next } \\
\text { Ending }\end{array}$ & $\begin{array}{c}\text { \% } \\
\text { [ndrent }\end{array}$ & $\begin{array}{c}\text { Next } \\
\text { Ending }\end{array}$ & \% \\
\hline \hline 1 & 00 & 00 & 18.36 & 14 & 14 & 1.47 \\
\hline 2 & 99 & 99 & 11.89 & 11 & 11 & 1.36 \\
\hline 3 & 95 & 95 & 8.83 & 15 & 15 & 1.28 \\
\hline 4 & 98 & 98 & 1.13 & 09 & 09 & 1.23 \\
\hline 5 & 00 & 99 & 0.89 & 13 & 13 & 1.16 \\
\hline 6 & 99 & 00 & 0.85 & 99 & 99 & 1.01 \\
\hline 7 & 99 & 95 & 0.72 & 12 & 12 & 0.80 \\
\hline 8 & 00 & 95 & 0.66 & 10 & 10 & 0.67 \\
\hline 9 & 99 & 98 & 0.64 & 08 & 08 & 0.63 \\
\hline 10 & 99 & 49 & 0.62 & 14 & 15 & 0.59 \\
\hline 11 & 49 & 99 & 0.62 & 16 & 16 & 0.58 \\
\hline 12 & 95 & 00 & 0.62 & 15 & 14 & 0.54 \\
\hline 13 & 95 & 99 & 0.57 & 14 & 13 & 0.49 \\
\hline 14 & 98 & 99 & 0.54 & 12 & 11 & 0.48 \\
\hline 15 & 49 & 49 & 0.28 & 13 & 14 & 0.48 \\
\hline 16 & 00 & 50 & 0.25 & 11 & 12 & 0.44 \\
\hline 17 & 88 & 88 & 0.24 & 22 & 22 & 0.43 \\
\hline 18 & 50 & 00 & 0.23 & 12 & 13 & 0.42 \\
\hline 19 & 85 & 85 & 0.20 & 13 & 12 & 0.42 \\
\hline 20 & 96 & 96 & 0.19 & 99 & 49 & 0.42 \\
\hline 21 & 89 & 99 & 0.19 & 19 & 19 & 0.41 \\
\hline 22 & 00 & 90 & 0.18 & 11 & 10 & 0.39 \\
\hline 23 & 96 & 99 & 0.18 & 21 & 21 & 0.39 \\
\hline 24 & 24 & 99 & 0.17 & 49 & 99 & 0.38 \\
\hline 25 & 97 & 97 & 0.16 & 10 & 11 & 0.35 \\
\hline \hline Note: Total number of price changes & & & & & & \\
\hline & & & & & & \\
\hline
\end{tabular}


Table 9. Top 25 Transition Probabilities Conditional on a Price Change

for a 100-State Markov Chain, by Price Level, Internet Data, for the Penny and Dime

Digits (LHS) and for the Dollar and \$10 Digits (RHS)

\begin{tabular}{|c|c|c|c|c|c|c|c|c|c|c|c|c|}
\hline \multirow[b]{3}{*}{$\begin{array}{c}\text { Ran } \\
\mathbf{k}\end{array}$} & \multicolumn{6}{|c|}{ Cents } & \multicolumn{6}{|c|}{ Dollars } \\
\hline & \multicolumn{3}{|c|}{$\begin{array}{c}\text { Low-Priced } \\
\text { Categories }\end{array}$} & \multicolumn{3}{|c|}{$\begin{array}{c}\text { High-Priced } \\
\text { Categories }\end{array}$} & \multicolumn{3}{|c|}{$\begin{array}{c}\text { Low-Priced } \\
\text { Categories }\end{array}$} & \multicolumn{3}{|c|}{$\begin{array}{c}\text { High-Priced } \\
\text { Categories } \\
\end{array}$} \\
\hline & $\begin{array}{c}\text { Curre } \\
\text { nt } \\
\text { Endin } \\
\text { g } \\
\end{array}$ & $\begin{array}{c}\text { Next } \\
\text { Endi } \\
\text { ng }\end{array}$ & $\%$ & $\begin{array}{c}\text { Curr } \\
\text { ent } \\
\text { Endi } \\
\text { ng } \\
\end{array}$ & $\begin{array}{c}\text { Next } \\
\text { Endin } \\
\mathbf{g}\end{array}$ & $\%$ & $\begin{array}{c}\text { Cur } \\
\text { rent } \\
\text { Endi } \\
\text { ng } \\
\end{array}$ & $\begin{array}{c}\text { Next } \\
\text { Endi } \\
\text { ng }\end{array}$ & $\%$ & $\begin{array}{c}\text { Cur } \\
\text { rent } \\
\text { Endi } \\
\text { ng } \\
\end{array}$ & $\begin{array}{c}\text { Next } \\
\text { Endi } \\
\text { ng }\end{array}$ & $\%$ \\
\hline 1 & 99 & 99 & 16.32 & 00 & 00 & 28.59 & 14 & 14 & 4.03 & 99 & 99 & 1.51 \\
\hline 2 & 98 & 98 & 1.80 & 95 & 95 & 12.77 & 11 & 11 & 3.72 & 99 & 49 & 0.65 \\
\hline 3 & 95 & 95 & 1.75 & 99 & 99 & 9.42 & 15 & 15 & 3.53 & 49 & 99 & 0.60 \\
\hline 4 & 99 & 98 & 1.19 & 00 & 99 & 1.34 & 09 & 09 & 3.31 & 99 & 79 & 0.54 \\
\hline 5 & 49 & 99 & 1.04 & 99 & 00 & 1.29 & 13 & 13 & 3.21 & 79 & 99 & 0.40 \\
\hline 6 & 98 & 99 & 0.97 & 00 & 95 & 1.02 & 12 & 12 & 2.18 & 99 & 89 & 0.39 \\
\hline 7 & 99 & 49 & 0.95 & 95 & 00 & 0.96 & 10 & 10 & 1.84 & 49 & 39 & 0.33 \\
\hline 8 & 96 & 96 & 0.50 & 99 & 95 & 0.94 & 08 & 08 & 1.62 & 49 & 49 & 0.28 \\
\hline 9 & 24 & 99 & 0.45 & 98 & 98 & 0.76 & 14 & 15 & 1.59 & 89 & 79 & 0.28 \\
\hline 10 & 99 & 24 & 0.42 & 95 & 99 & 0.75 & 16 & 16 & 1.55 & 79 & 69 & 0.28 \\
\hline 11 & 96 & 99 & 0.40 & 99 & 49 & 0.44 & 15 & 14 & 1.40 & 39 & 29 & 0.27 \\
\hline 12 & 89 & 99 & 0.37 & 00 & 50 & 0.39 & 13 & 14 & 1.26 & 49 & 29 & 0.25 \\
\hline 13 & 88 & 88 & 0.37 & 49 & 99 & 0.39 & 14 & 13 & 1.25 & 29 & 99 & 0.25 \\
\hline 14 & 99 & 95 & 0.34 & 50 & 00 & 0.35 & 12 & 11 & 1.17 & 99 & 69 & 0.25 \\
\hline 15 & 99 & 19 & 0.33 & 99 & 98 & 0.33 & 11 & 12 & 1.16 & 99 & 94 & 0.24 \\
\hline 16 & 82 & 82 & 0.28 & 49 & 49 & 0.32 & 22 & 22 & 1.15 & 59 & 49 & 0.23 \\
\hline 17 & 99 & 89 & 0.27 & 98 & 99 & 0.30 & 12 & 13 & 1.12 & 99 & 98 & 0.23 \\
\hline 18 & 19 & 99 & 0.26 & 85 & 85 & 0.29 & 13 & 12 & 1.06 & 79 & 49 & 0.22 \\
\hline 19 & 95 & 99 & 0.26 & 00 & 90 & 0.27 & 19 & 19 & 1.06 & 19 & 99 & 0.22 \\
\hline 20 & 99 & 39 & 0.25 & 97 & 97 & 0.22 & 21 & 21 & 1.01 & 69 & 59 & 0.21 \\
\hline 21 & 99 & 29 & 0.25 & 90 & 00 & 0.20 & 11 & 10 & 0.94 & 89 & 99 & 0.21 \\
\hline 22 & 49 & 59 & 0.24 & 94 & 99 & 0.18 & 10 & 11 & 0.90 & 99 & 29 & 0.20 \\
\hline 23 & 49 & 49 & 0.22 & 90 & 90 & 0.17 & 23 & 23 & 0.84 & 29 & 19 & 0.20 \\
\hline 24 & 09 & 95 & 0.21 & 99 & 94 & 0.17 & 16 & 17 & 0.78 & 09 & 99 & 0.20 \\
\hline 25 & 59 & 69 & 0.21 & 88 & 88 & 0.17 & 17 & 16 & 0.74 & 19 & 09 & 0.18 \\
\hline
\end{tabular}

Note: Low-priced categories include CDs, DVDs, and Video Games. High-priced categories include Computer Monitors, Digital Cameras, DVD Players, Hard Drives, Laptop Computers, PDAs, and Software. 
Table 10. Results of the Logit Regression (Equation 1) Estimation

for the Dominick’s Data, Regular Prices, Stores \#8, \#12, \#122 and \#133

\begin{tabular}{|c|c|c|c|c|}
\hline \multirow[b]{2}{*}{ Category } & \multicolumn{2}{|c|}{$\begin{array}{c}\text { 9థ-Ending } \\
\left(9-\text { Ending }_{9}=1\right)\end{array}$} & \multicolumn{2}{|c|}{$\begin{array}{c}\text { 99థ-Ending } \\
\left(9-\text { Ending }_{99}=1\right)\end{array}$} \\
\hline & Coefficient & Odds Ratio & Coefficient & Odds Ratio \\
\hline Analgesics & -1.4820 & 0.23 & -0.3599 & 0.70 \\
\hline Bath Soap & -1.6871 & 0.19 & -0.7683 & 0.46 \\
\hline Bathroom Tissues & -0.4763 & 0.62 & -0.0353 & 0.97 \\
\hline Bottled Juices & -0.7232 & 0.49 & -0.4984 & 0.61 \\
\hline Canned Soup & -0.4553 & 0.63 & -0.6055 & 0.55 \\
\hline Canned Tuna & -0.7692 & 0.46 & -0.5518 & 0.58 \\
\hline Cereals & -0.5013 & 0.61 & -0.3582 & 0.70 \\
\hline Cheeses & -1.7457 & 0.17 & -1.1008 & 0.33 \\
\hline Cookies & -2.1156 & 0.12 & -1.1052 & 0.33 \\
\hline Crackers & -1.8639 & 0.16 & -0.9784 & 0.38 \\
\hline Dish Detergent & -1.0433 & 0.35 & -0.7082 & 0.49 \\
\hline Fabric Softeners & -0.6951 & 0.50 & -0.3909 & 0.68 \\
\hline Front-End Candies & -0.8917 & 0.41 & -1.5532 & 0.21 \\
\hline Frozen Dinners & -1.3773 & 0.25 & -0.6168 & 0.54 \\
\hline Frozen Entrees & -1.1704 & 0.31 & -0.6649 & 0.51 \\
\hline Frozen Juices & -0.3795 & 0.68 & -0.0395 & 0.96 \\
\hline Grooming Products & -2.2234 & 0.11 & -0.6918 & 0.50 \\
\hline Laundry Detergents & -1.5275 & 0.22 & -0.5607 & 0.57 \\
\hline Oatmeal & -1.0142 & 0.36 & -0.2450 & 0.78 \\
\hline Paper Towels & -0.6164 & 0.54 & -0.7879 & 0.45 \\
\hline Refrigerated Juices & -0.8902 & 0.41 & -0.4119 & 0.66 \\
\hline Shampoos & -2.1695 & 0.11 & -0.3264 & 0.72 \\
\hline Snack Crackers & -1.9320 & 0.14 & -0.8181 & 0.44 \\
\hline Soaps & -1.6669 & 0.19 & -0.6347 & 0.53 \\
\hline Soft Drinks & -3.1645 & 0.04 & -0.6425 & 0.53 \\
\hline Tooth Brushes & -0.9833 & 0.37 & -0.5719 & 0.56 \\
\hline Tooth Pastes & -0.6796 & 0.51 & -0.6291 & 0.53 \\
\hline Average & & 0.34 & & 0.57 \\
\hline \multicolumn{5}{|c|}{ 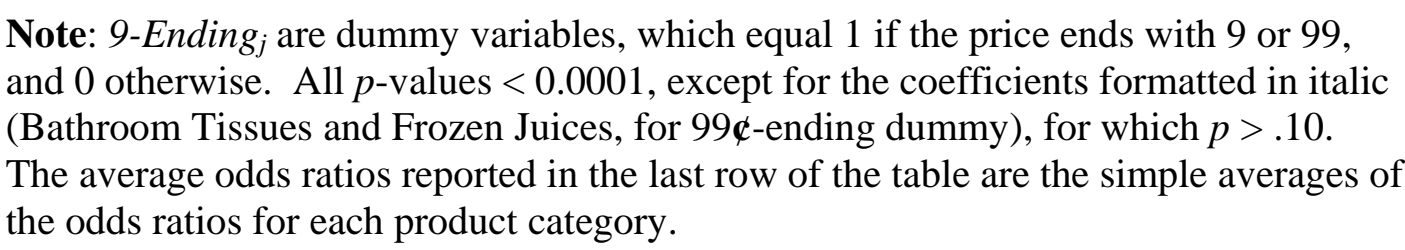 } \\
\hline
\end{tabular}


Table 11. Results of Logit Regression (Equation 1) Estimation for the Internet Dataset

\begin{tabular}{|c|c|c|c|c|c|c|}
\hline Category & $\begin{array}{c}94- \\
\text { Endings }\end{array}$ & $\begin{array}{c}\text { 994- } \\
\text { Endings }\end{array}$ & $\begin{array}{c}\text { \$9- } \\
\text { Endings }\end{array}$ & $\begin{array}{c}\text { \$99- } \\
\text { Endings }\end{array}$ & $\begin{array}{c}\text { \$9.99- } \\
\text { Endings }\end{array}$ & $\begin{array}{l}\text { \$99.99- } \\
\text { Endings }\end{array}$ \\
\hline Music CDs & $\begin{array}{c}-0.0727^{* *} \\
(0.9299)\end{array}$ & $\begin{array}{c}-0.5463^{* * *} \\
(0.5791)\end{array}$ & $\begin{array}{c}-0.0125^{* * *} \\
(0.9876)\end{array}$ & & $\begin{array}{c}-0.4430^{* *} \\
(0.6421)\end{array}$ & \\
\hline Movie DVDs & $\begin{array}{c}-0.4716^{* * *} \\
(0.6240)\end{array}$ & $\begin{array}{c}-0.5827^{* * *} \\
(0.5584)\end{array}$ & $\begin{array}{c}-0.3551^{* * *} \\
(0.7011)\end{array}$ & & $\begin{array}{c}-0.9068^{* * *} \\
(0.4038)\end{array}$ & \\
\hline Video Games & $\begin{array}{l}0.1630 \\
(1.1770)\end{array}$ & $\begin{array}{l}0^{0.0729}{ }^{* * *} \\
(1.0756)\end{array}$ & $\begin{array}{c}-0.3572^{* * *} \\
(0.6996)\end{array}$ & & $\begin{array}{c}-0.2807^{* * *} \\
(0.7553)\end{array}$ & \\
\hline Software & $\begin{array}{c}-0.3185^{* * *} \\
(0.7272)\end{array}$ & $\begin{array}{c}-0.4998^{* * *} \\
(0.6067)\end{array}$ & $\begin{array}{c}-0.5892^{* * *} \\
(0.5548)\end{array}$ & $\begin{array}{c}-1.0831^{* * *} \\
(0.3385)\end{array}$ & $\begin{array}{c}-0.8032^{* * *} \\
(0.4479)\end{array}$ & $\begin{array}{c}-1.4014^{* * *} \\
(0.2463)\end{array}$ \\
\hline PDAs & $\begin{array}{c}-0.14966^{* *} \\
(0.8611)\end{array}$ & $\begin{array}{c}-0.2253^{* * *} \\
(0.7983)\end{array}$ & $\begin{array}{c}-0.4370^{* * *} \\
(0.6460)\end{array}$ & $\begin{array}{c}-0.5944^{* * *} \\
(0.5519)\end{array}$ & $\begin{array}{c}-0.4041^{* * *} \\
(0.6676)\end{array}$ & $\begin{array}{c}-0.8986^{* * *} \\
(0.4071)\end{array}$ \\
\hline Hard Drives & $\begin{array}{c}-0.2276^{* * *} \\
(0.7964)\end{array}$ & $\begin{array}{c}-0.2777^{* * *} \\
(0.7575)\end{array}$ & $\begin{array}{c}-0.3368^{* * *} \\
(0.7141)\end{array}$ & $\begin{array}{c}-0.3242^{* * *} \\
(0.7231)\end{array}$ & $\begin{array}{c}-0.5197^{* * *} \\
(0.5947)\end{array}$ & $\begin{array}{c}-0.6072^{* * *} \\
(0.5449)\end{array}$ \\
\hline DVD Players & $\begin{array}{c}-0.5161^{* * *} \\
(0.5968)\end{array}$ & $\begin{array}{c}-0.5808^{* * *} \\
(0.5595)\end{array}$ & $\begin{array}{c}-0.7455^{* * *} \\
(0.4745)\end{array}$ & $\begin{array}{l}-0.5246^{* * *} \\
(0.5918)\end{array}$ & $\begin{array}{c}-0.6718^{* * *} \\
(0.5108)\end{array}$ & $\begin{array}{c}-0.6074^{* * *} \\
(0.5448)\end{array}$ \\
\hline PC Monitors & $\begin{array}{c}-0.1893^{* * *} \\
(0.8275)\end{array}$ & $\begin{array}{c}-0.3734^{* * *} \\
(0.6884)\end{array}$ & $\begin{array}{c}-0.5445^{* * *} \\
(0.5801)\end{array}$ & $\begin{array}{c}-0.7598^{* * *} \\
(0.4678)\end{array}$ & $\begin{array}{c}-0.7457^{* * *} \\
(0.4744)\end{array}$ & $\begin{array}{c}-1.3102^{* * *} \\
(0.2698)\end{array}$ \\
\hline $\begin{array}{l}\text { Digital } \\
\text { Cameras }\end{array}$ & $\begin{array}{c}-0.3634^{\text {*** }} \\
(0.6953)\end{array}$ & $\begin{array}{c}-0.4199^{* * *} \\
(0.6571)\end{array}$ & $\begin{array}{c}-0.4464^{* * *} \\
(0.6339)\end{array}$ & $\begin{array}{c}-0.9363^{* * *} \\
(0.3921)\end{array}$ & $\begin{array}{c}-0.5052^{* * *} \\
(0.6034)\end{array}$ & $\begin{array}{c}-1.1454^{* * *} \\
(0.3181)\end{array}$ \\
\hline $\begin{array}{l}\text { Notebook } \\
\text { PCs }\end{array}$ & $\begin{array}{c}-0.3583^{\text {*** }} \\
(0.6989)\end{array}$ & $\begin{array}{c}-0.5335^{* * *} \\
(0.5865)\end{array}$ & $\begin{array}{c}-0.7383^{* * *} \\
(0.4779)\end{array}$ & $\begin{array}{c}-0.5533^{* * *} \\
(0.5750)\end{array}$ & $\begin{array}{c}-0.7014^{* * *} \\
(0.4959)\end{array}$ & $\begin{array}{c}-0.7149^{* *} \\
(0.4892)\end{array}$ \\
\hline Total & $\begin{array}{c}-0.2800^{\text {*** }} \\
(0.7558)\end{array}$ & $\begin{array}{c}-0.4330^{\text {**** }} \\
(0.6486)\end{array}$ & $\begin{array}{c}-0.4378^{* * * *} \\
(0.6455)\end{array}$ & $\begin{array}{c}-0.7787^{* * *} \\
(0.4590)\end{array}$ & $\begin{array}{c}-0.5841^{* * *} \\
(0.5576)\end{array}$ & $\begin{array}{c}-1.0201^{* * *} \\
(0.3606)\end{array}$ \\
\hline
\end{tabular}


Table 12. Comparing Average Size of Price Change Between 9- and Non-9-Ending Prices: for Dominick’s (Regular Prices; Stores \#8, \#12, \#122 and \#133) and for the Internet

\begin{tabular}{|c|c|c|c|c|c|c|c|c|}
\hline & \multicolumn{4}{|c|}{ All Products } & \multicolumn{4}{|c|}{$\begin{array}{l}\text { Low Quartile of Products in Terms } \\
\text { of Popularity of 9-Ending Prices }\end{array}$} \\
\hline & 9-Endings & $\begin{array}{c}\text { Non-9- } \\
\text { Endings }\end{array}$ & $t$-Stat & $p$-Value & $\begin{array}{c}\text { 9- } \\
\text { Endings }\end{array}$ & $\begin{array}{c}\text { Non-9- } \\
\text { Endings }\end{array}$ & $t$-Stat & $p$-Value \\
\hline \multicolumn{9}{|c|}{ Dominick's } \\
\hline 94 & $\$ \$ 0.75$ & $\$ 0.40$ & 934.87 & .000 & $\$ 0.38$ & $\$ 0.33$ & 27.61 & .000 \\
\hline 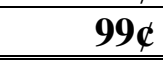 & $\$ 0.91$ & $\$ 0.55$ & 721.24 & .000 & $\$ 0.49$ & $\$ 0.34$ & 53.64 & .000 \\
\hline \multicolumn{9}{|l|}{ Internet } \\
\hline 94 & $\$ 15.54$ & \$18.07 & -4.50 & .000 & $\$ 24.02$ & \$21.03 & 2.75 & 2.006 \\
\hline $99 c$ & $\$ 22.40$ & $\$ 16.78$ & 5.55 & .000 & $\$ 27.78$ & $\$ 20.76$ & 4.56 & .000 \\
\hline$\$ 9$ & $\$ 32.13$ & $\$ 12.83$ & 33.65 & .000 & $\$ 11.93$ & $\$ 7.21$ & 5.67 & .000 \\
\hline$\$ 9.99$ & $\$ 33.97$ & $\$ 16.30$ & 17.34 & .000 & $\$ 22.47$ & $\$ 7.38$ & 5.99 & .000 \\
\hline$\$ 99$ & $\$ 66.15$ & $\$ 15.20$ & 42.89 & .000 & $\$ 49.61$ & $\$ 18.27$ & 8.56 & .000 \\
\hline$\$ 99.99$ & $\$ 63.04$ & $\$ 16.88$ & 19.93 & .000 & $\$ 38.24$ & $\$ 19.21$ & 4.78 & .000 \\
\hline
\end{tabular}


Figure 1. Frequency Distribution of the Last Digit in the Dominick’s Data, Regular Prices, Stores \#8, \#12, \#122 and \#133

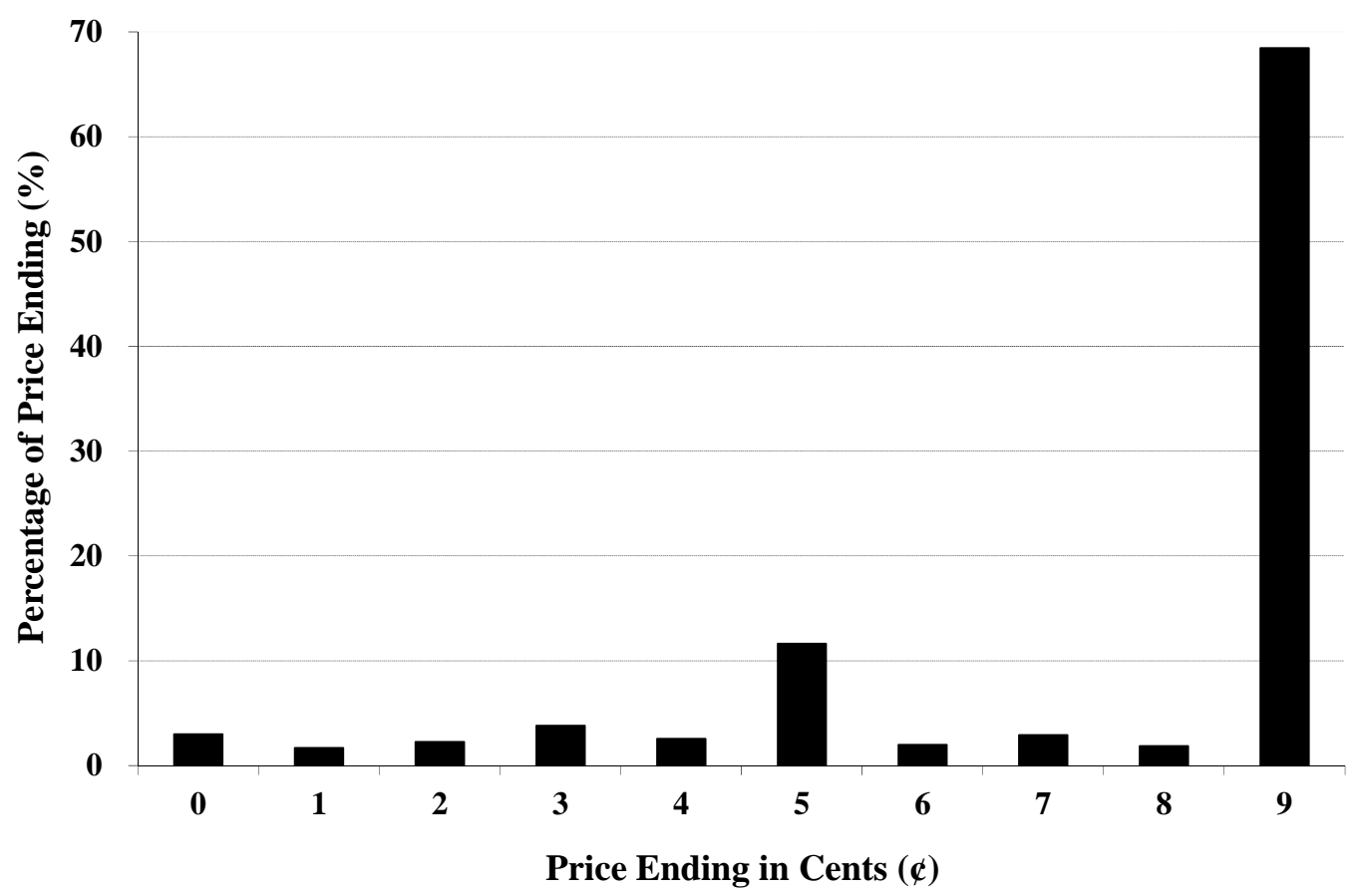


Figure 2. Frequency Distribution of the Last Two Digits

in the Dominick’s Data, Regular Prices; Stores \#8, \#12, \#122 and \#133

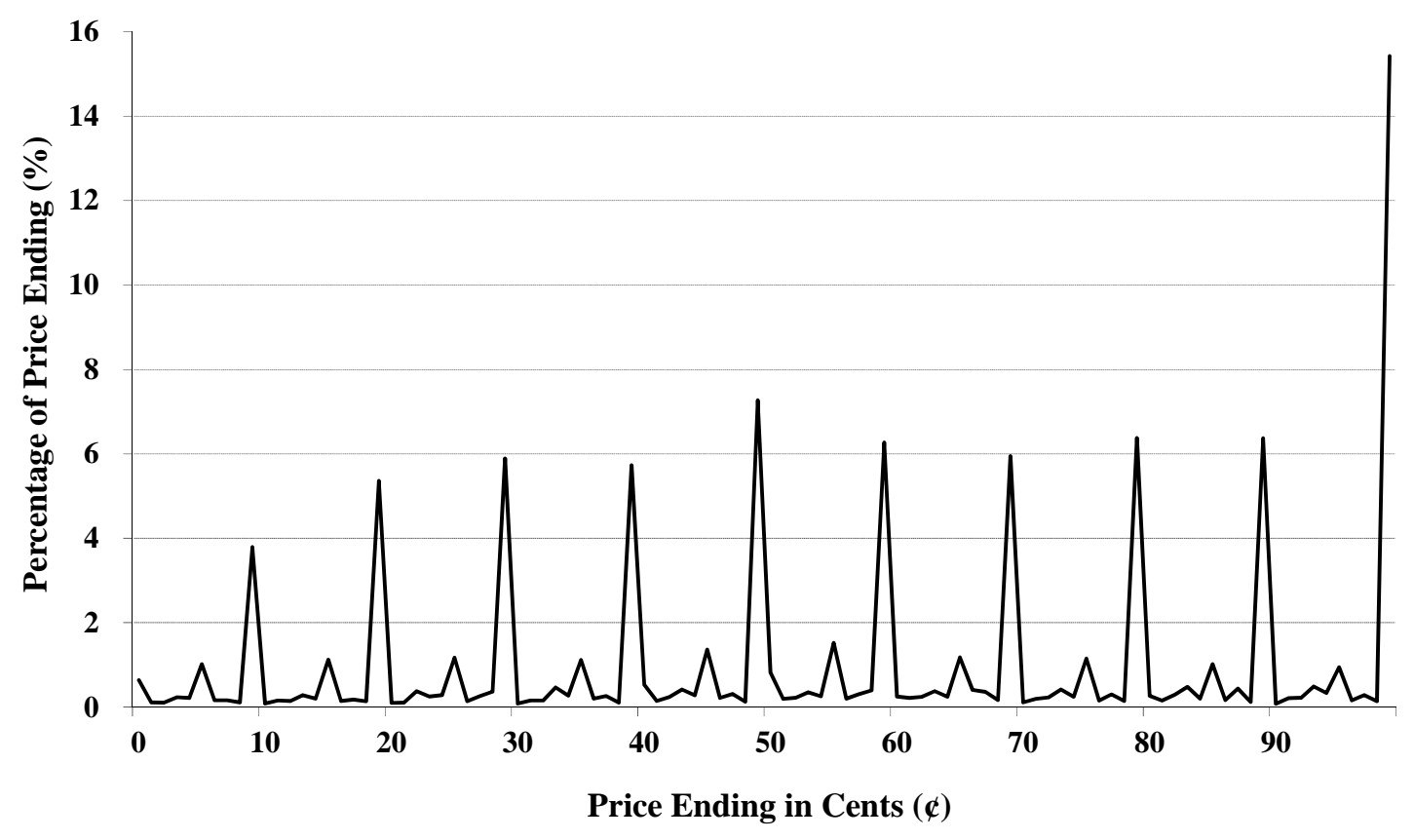


Figure 3. Frequency Distribution of the Last Digit in the Internet Data

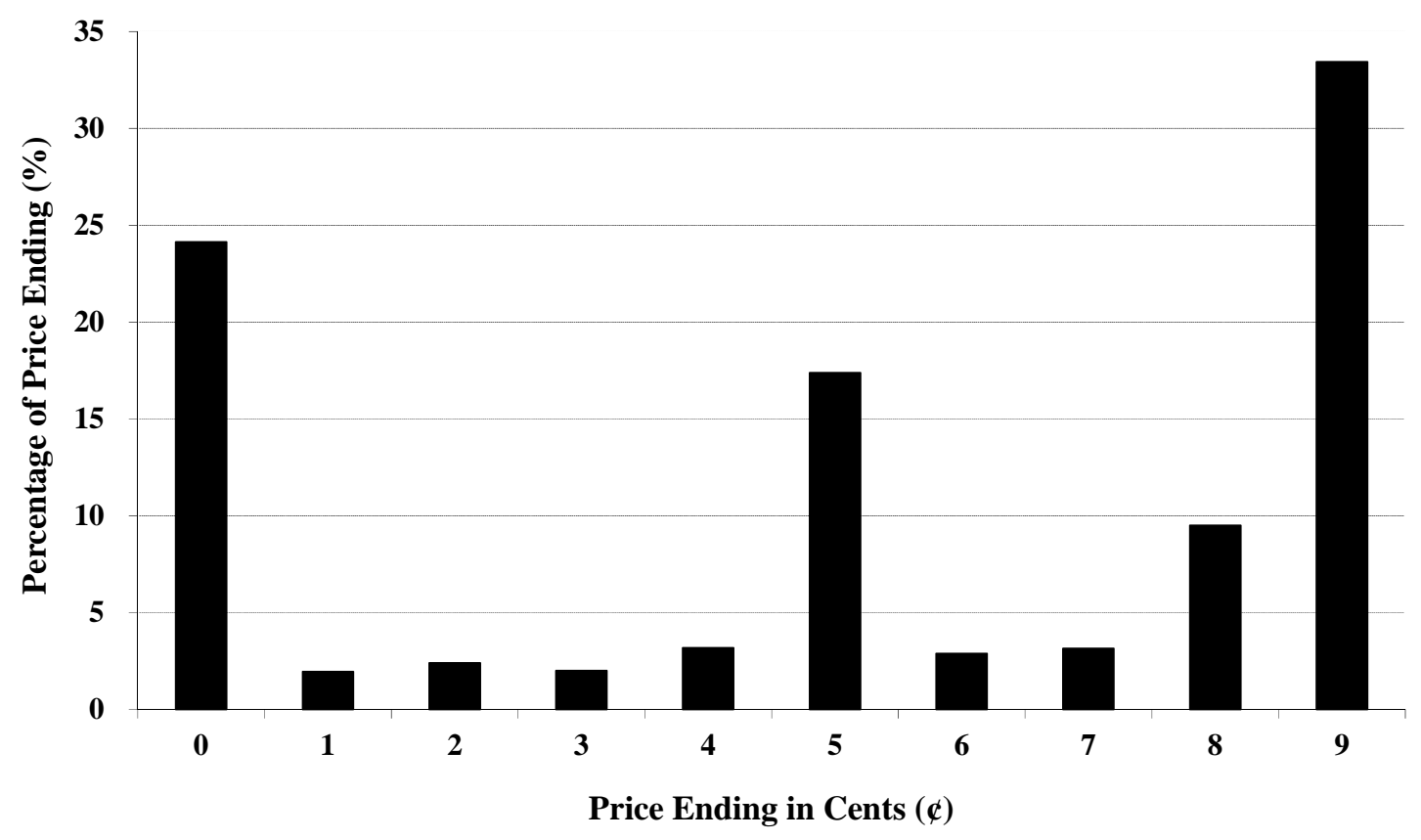


Figure 4. Frequency Distribution of the Last Two Digits in the Internet Data

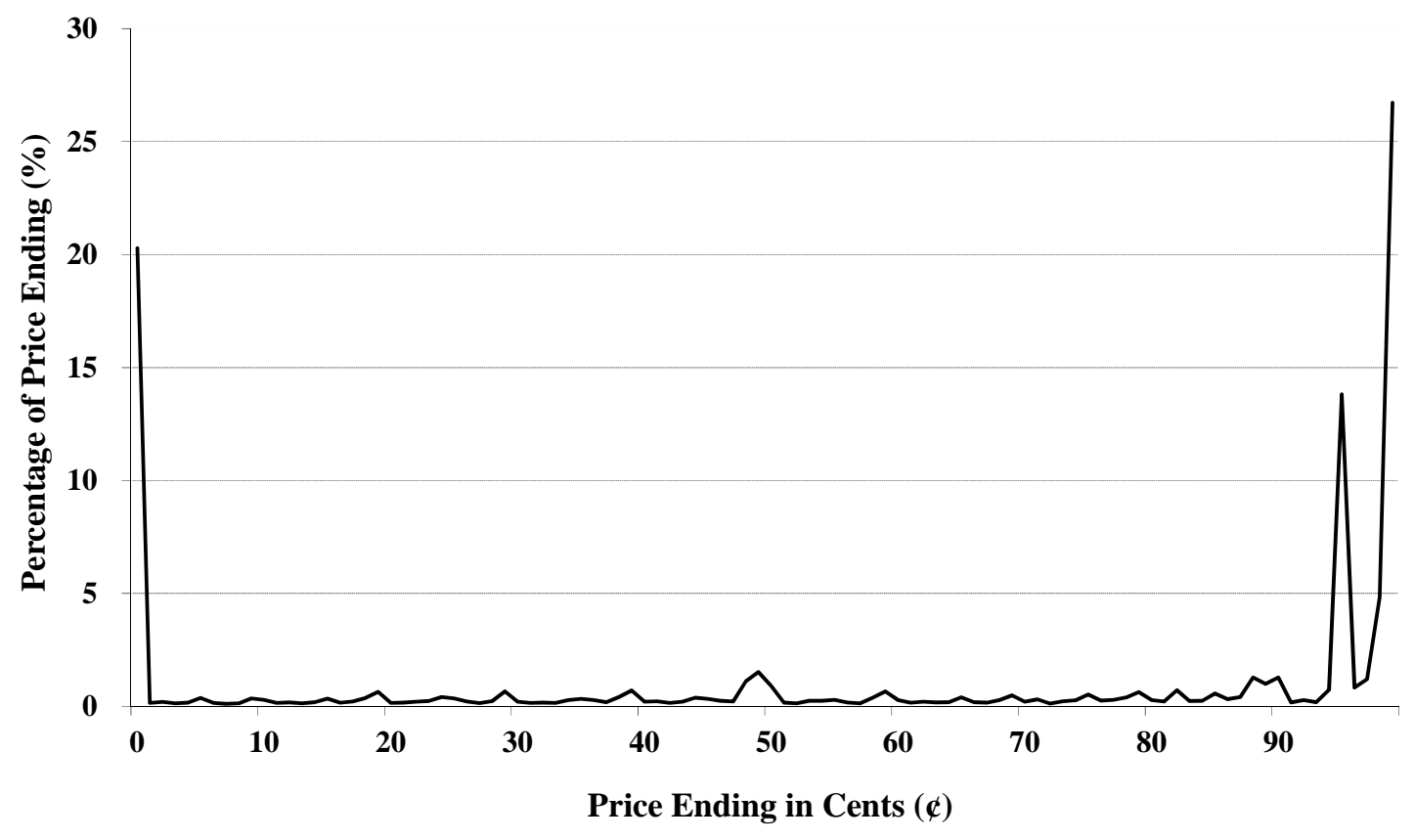


Figure 5. Frequency Distribution of the Last Dollar Digit in the Internet Data

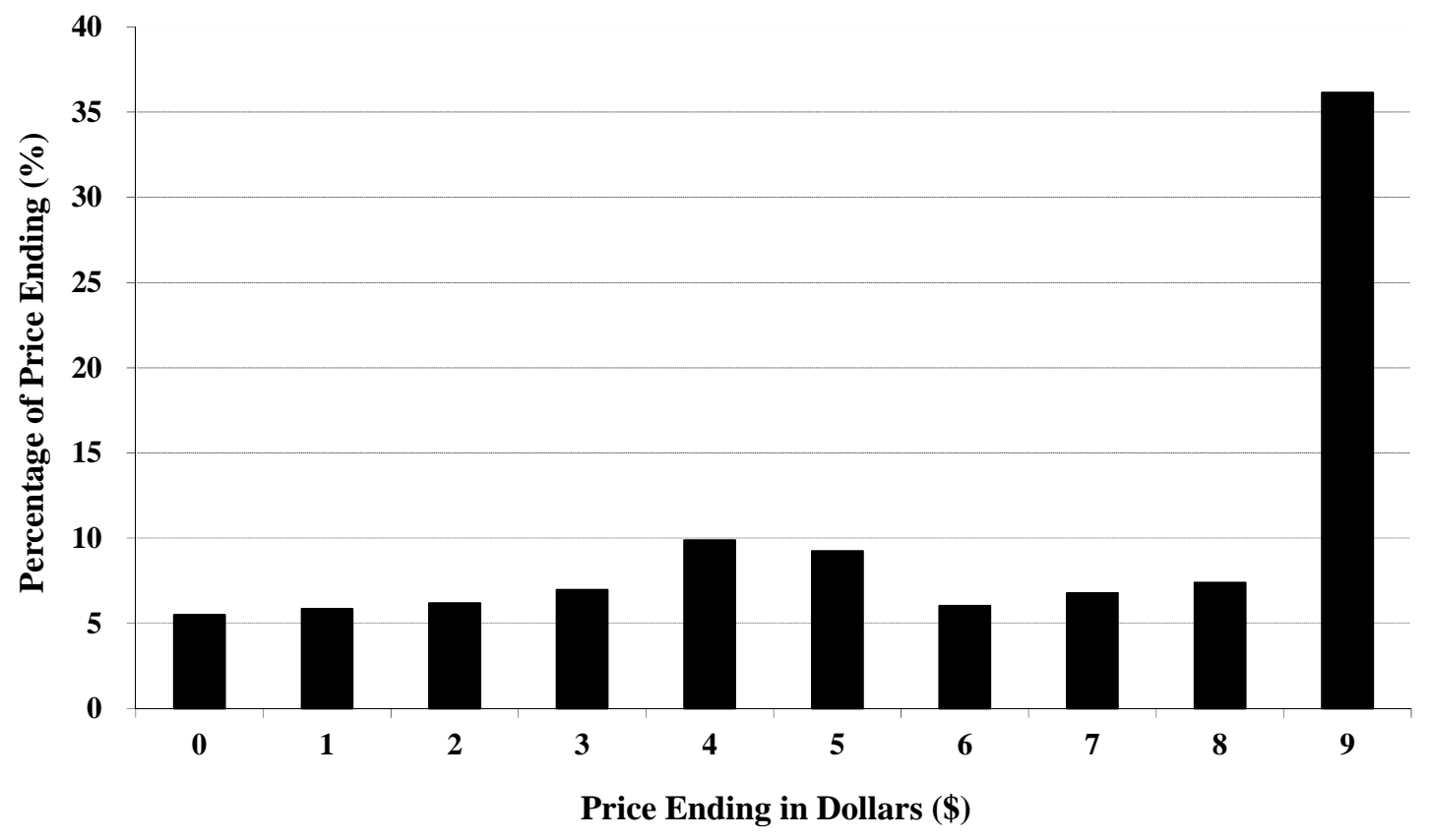


Figure 6. Frequency Distribution of the Last Two Dollar Digits in the Internet Data

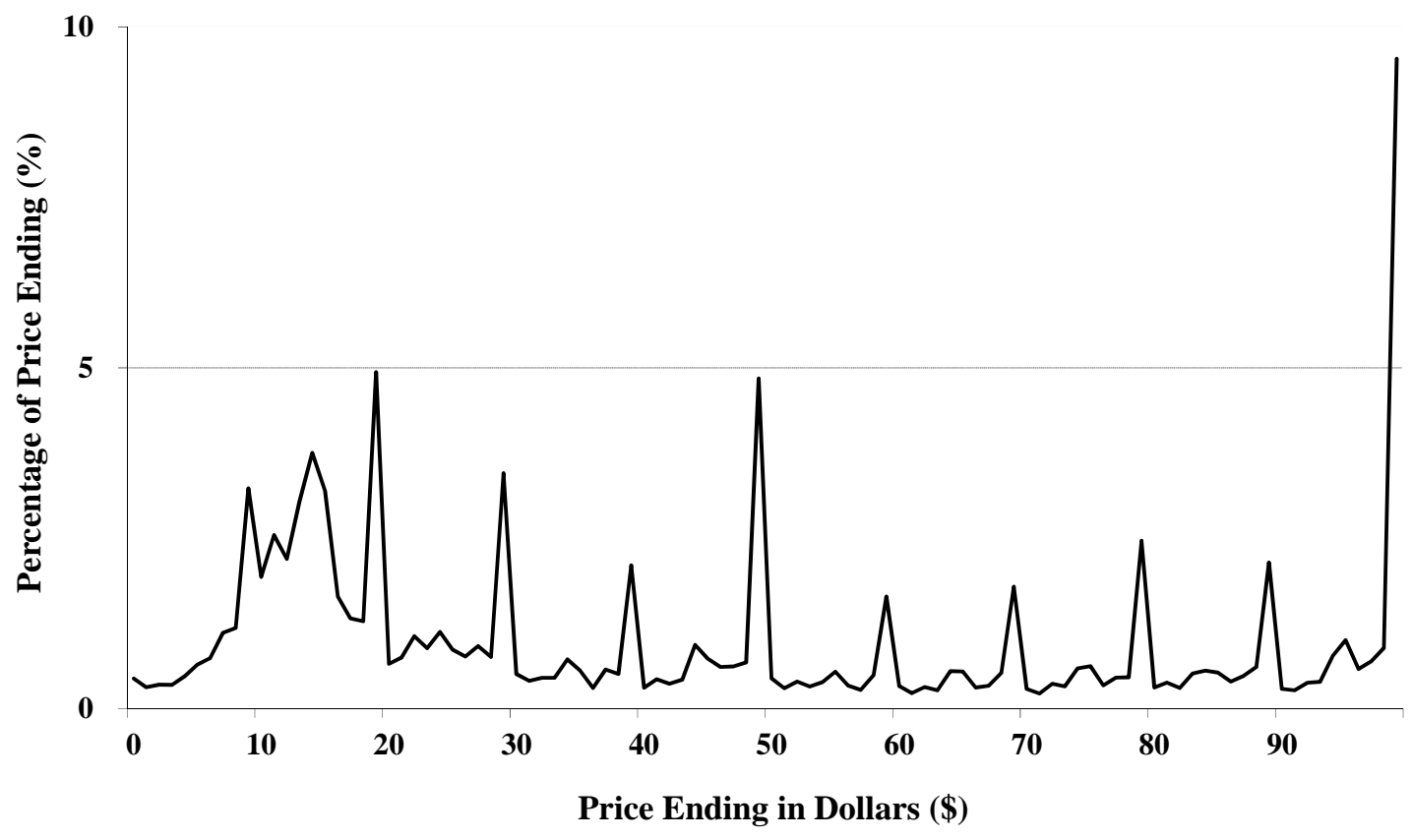


${ }^{1}$ See, for example, Carlton (1986), Cecchetti (1986), Warner and Barsky (1995), Danziger (1999, 2007), Dutta, et al. (2002), Levy, et al. (1998, 2002, 2010), Ball and Romer (2003), Rotemberg (1987, 2005, 2010), Nakamura and Steinsson (2008, 2009), Kehoe and Midrigan (2010), Klenow and Kryvtsov (2008), Eichenbaum, et al. (2010), Alvarez, et al. (2010), and Midrigan (2010). For recent surveys, see Willis (2003), Wolman (2007), and Klenow and Malin (2010).

${ }^{2}$ The products in Beers and Cigarettes categories are highly regulated, which might skew the results (Besley and Rosen, 1999). We, therefore, do not discuss the results for these two categories.

${ }^{3}$ Dominick's data are available at http://research.chicagobooth.edu/marketing/databases/dominicks/stores.aspx. The site contains detailed information about the location of the stores, as well as detailed description of the data files, product categories included, etc. The site also discusses various measurement issues.

${ }^{4}$ When the sellers' websites were inaccessible or the price information was not available, instances of missing data occurred. The software agent used the following algorithm to address this issue. If $10 \%$ or more observations were missing for a product, then that series was excluded from the data altogether. If less than $10 \%$ of the data were missing, then the algorithm examined if the prices for the day before and the day after were the same. If they were the same, then the software agent automatically filled in the missing data with that price. Otherwise, it filled in the missing data with the price for the day after. Only $0.075 \%$ of the Internet dataset was interpolated this way because of missing observations, and thus missing data are unlikely to affect our results. 
${ }^{5}$ Product categories were selected based on their popularity on the Internet. The products in these categories were sold by a large number of stores. For example, in the category of Digital Cameras, the "Canon-EOS Digital Rebel XT” was sold by 63 stores. Our selection of products was random. For example, in the category of Movie DVDs, we chose products from multiple sub-categories (e.g., Action, Drama, Comedy, etc.). Similarly, in the Music CDs category, we chose from many different sub-categories (e.g., Blues, Jazz, Country, etc.). However, in some categories (e.g., Notebook PCs and Hard Drives), we included all of the available products. In other categories (e.g., DVD Players, Digital Cameras, PC Monitors, Software), we randomly chose products from all of the sub-categories. For example, in the DVD Players category, we chose half of the products from among Standard DVD Players, while the other half came from the more expensive DVD/VCR Combo Players. In the Digital Cameras and Camcorders categories, we chose half from Regular Digital Cameras while the other half came from Digital Camcorders. For PC Monitors, we chose half from CRTs and Flat CRTs, and the other half from LCDs and TFTs. In the Software category, we chose products from multiple genres (e.g., Educational Software, Operating Systems, Programming Software, Utility Software, etc.). Similarly, for Video Games, we included multiple genres (adventure, action, sports, etc.). See Figures R8a-R8j in the supplementary appendix for sample price series from our Internet dataset.

${ }^{6}$ Indeed, according to Dutta et al. (1999) and Levy et al. $(1997,1998)$, the average price of an item in large U.S. supermarket chains during 1991-1992 was about \$1.70. Bergen et al. (2008) have noted that the figure increased to $\$ 2.08$ by 2001. In our four-store sample, the average price is $\$ 2.67$. See Table 1 . 
${ }^{7}$ In an earlier analysis, we ran the above regression without the product dummies and obtained similar results. When we correlated the proportion of 9-ending prices for each product category with the regression coefficient of the 9-dummy from this earlier analysis, we obtained a significantly negative correlation for the $9 \nsubseteq$ ending prices, suggesting the presence of some product specific effects. For the $99 \$$-ending prices the correlation coefficient was positive but statistically insignificant. We chose to include the product dummies in the results we report here. ${ }^{8}$ Three individual product categories with low average prices exhibited some variation in their price endings. For example, for the dollar digit, the $\$ 3$, \$4 and \$5 price-endings were the most common for CDs and DVDs. That is because the prices in these categories usually range between $\$ 13$ and \$16. Also, the \$99 and \$99.99 endings were not common in those two categories or the category of Video Games, because the average prices in these categories are less than $\$ 100$. We, therefore, did not see frequent 9-endings for the dollar and ten-dollar digits in these categories.

${ }^{9}$ Two categories, Music CDs and Video Games, contained no prices with a \$99-and $\$ 99.00$ endings.

${ }^{10}$ There were no Music CDs, Music DVDs or Video Games with \$99- or with \$99.99-ending prices.

${ }^{11}$ See, for example, http://www.globes.co.il/news/article.aspx?did=1000403091 (in Hebrew).

${ }^{12}$ In the July 19, 2001 issue of the USA Today, L. Copland reported that "France, Spain and Britain quit producing low-denomination coins in recent decades because production costs kept going up while the coins’ purchasing power went down.” More recently, it has been reported that in many European countries which have adopted the Euro, the public seems to be exhibiting resistance to the use of 1-cent and 2-cent denomination coins. This is due to the inconvenience 
their use entails. In the March 22, 2002 issue of the International Herald Tribune (Tel-Aviv Edition), E. Pfanner suggested that these coins are "small, nearly valueless—and a nuisance to millions of Europeans. The tiny denominations of the 1-cent and 2-cent Euro coins are annoying shoppers and disrupting business from Paris to Milan.” According to the above USA Today report, in 2001, Rep. Jim Kolbe (R-Arizona) introduced the "Legal Tender Modernization Act,” to make the U.S. penny obsolete. The bill was defeated. Previous attempts made in 1990 and 1996 also died in Congress.

${ }^{13}$ A recent New York Time report (Toy, 2010) lists numbers that have particular significance in some cultures. Even the sounds of the numbers can suggest good or bad luck. For example, the number 8 represents luck to Cantonese Chinese because it sounds like multiply or get rich (fa in Cantonese). In Japan, 8 also has great symbolic significance because the writing of the number 8 looks like a mountain (“八”), and thus the number 8 signifies growth and prosperity. In the Jewish culture the number 18 has a special significance because numerically it is equivalent to chai which means life, and therefore, donations made by Jews are often in multiples of 18 . In the Indian society, the person's birth date is used to determine the person's lucky numbers based on Vedic astrology.

${ }^{14}$ The cultural importance of numbers is not limited to "happy endings.” For example, according to Mirhadi (2000), when the Masquerade Tower was added to Hotel Rio in Las Vegas in 1997, the architects decided to skip the 40th to the 49th floors because the Arabic numeral " 4 " in Chinese sounds similar to the word "death.” The elevators in the building went directly from the 39th floor to the 50th floor. According to Toy (2010), in many residential and commercial buildings the 13th floor is missing, skipping from the 12th floor to the 14th floor. 